\title{
ANALYSIS OF DAMAGE DATA COLLECTED FOR WINE STORAGE TANKS FOLLOWING THE 2013 AND 2016 NEW ZEALAND EARTHQUAKES
}

\author{
Mohsen Yazdanian ${ }^{1}$, Jason Ingham ${ }^{2}$, Christopher Kahanek ${ }^{3}$, \\ Nicholas Cradock-Henry ${ }^{4}$, Joanna Fountain ${ }^{5}$ and Dmytro Dizhur ${ }^{6}$
}

(Submitted October 2019; Reviewed November 2019; Accepted March 2020)

\begin{abstract}
The 2013 Seddon earthquake $\left(M_{\mathrm{w}} 6.5\right)$, the 2013 Lake Grassmere earthquake $\left(\mathrm{M}_{\mathrm{w}} 6.6\right)$, and the 2016 Kaikōura earthquake $\left(M_{\mathrm{w}} 7.8\right)$ provided an opportunity to assemble the most extensive damage database to wine storage tanks ever compiled worldwide. An overview of this damage database is presented herein based on the in-field post-earthquake damage data collected for 2058 wine storage tanks (1512 legged tanks and 546 flat-based tanks) following the 2013 earthquakes and 1401 wine storage tanks (599 legged tanks and 802 flat-based tanks) following the 2016 earthquake. Critique of the earthquake damage database revealed that in $2013,39 \%$ and $47 \%$ of the flat-based wine tanks sustained damage to their base shells and anchors respectively, while due to resilience measures implemented following the 2013 earthquakes, in the 2016 earthquake the damage to tank base shells and tank anchors of flat-based wine tanks was reduced to $32 \%$ and $23 \%$ respectively and instead damage to tank barrels (54\%) and tank cones (43\%) was identified as the two most frequently occurring damage modes for this type of tank. Analysis of damage data for legged wine tanks revealed that the frame-legs of legged wine tanks sustained the greatest damage percentage among different parts of legged tanks in both the 2013 earthquakes (40\%) and in the 2016 earthquake (44\%). Analysis of damage data and socio-economic findings highlight the need for industry-wide standards, which may have socio-economic implications for wineries.
\end{abstract}

\section{INTRODUCTION}

The New Zealand wine industry contributes more than NZ\$1.7 billion per year to the national economy, with the average annual growth in New Zealand wine exports over the last two decades being $17 \%$ [1], resulting in the wine industry being one of the fastest-growing and currently the $5^{\text {th }}$ largest goods export industry in New Zealand [2], with New Zealand wine being exported to more than 90 countries around the world. Approximately $68 \%$ of all New Zealand wine resources are produced in the Marlborough region [1], which is located at the north-eastern tip of the South Island. According to the New Zealand seismic hazard map reported in NZS 1170.5:2004 [3], the Marlborough region is a high seismic zone and historically several significant earthquakes have affected the Marlborough region. The latest earthquakes to significantly impact the Marlborough region were the 2013 Seddon earthquake ( $\left.M_{\mathrm{w}} 6.5\right)$, the 2013 Lake Grassmere earthquake $\left(M_{\mathrm{w}}\right.$ 6.6), and the 2016 Kaikoura earthquake $\left(\mathrm{M}_{\mathrm{w}} 7.8\right)$, which each caused damage to winery facilities in the region (see [4-8]).

Winemaking facilities typically consist of four important elements, being the buildings, the barrel racks, the catwalks (see Figure 1), and the wine storage tanks (see Figure 2). Following earthquakes in Marlborough in 2013 and 2016 engineering teams inspected earthquake-affected wineries and collected detailed damage data. Analysis of this post-earthquake damage data in combination with a review of pertinent technical literature revealed that wine storage tanks sustained the largest proportion of damage within the wineries (see [4-7]). Wine storage tanks can be divided into two types based on their support conditions: (1) flat-based tanks and (2) legged tanks (see Figure 2). The non-legged wine tanks reported in the current study are referred to here as flat-based tanks, where the reference to "flat" does not specifically indicate that the tank base shell is horizontal because flat-based tanks can be mounted over a slopped concrete plinth, but these tanks are directly supported on a foundation slab.

Much research has been undertaken to investigate the dynamic behaviour of water and petroleum storage tanks that are typically composed of steel material that is different from the steel used to manufacture wine tanks, which in some cases have an open top or a floating roof, and that mostly have a low height to radius $(\mathrm{H} / \mathrm{R})$ aspect ratio and are either anchored or are unanchored to their foundation and rest on a concrete ring wall (e.g. see [9-25]). Currently limited research has been reported on damage data associated with wine storage tanks, with the most comparable earthquake damage data available being collected between 1933 and 1995 and reported by Cooper [26] based on an inventory of 424 water and petroleum storage tanks. This database was later reviewed and updated by ALA [27-28] to include an additional 108 storage tanks and an adjusted definition of damage states. It is particularly noteworthy that this earthquake damage database is limited to anchored and unanchored oil and water storage tanks, and that currently there is a comparative absence of comprehensive earthquake damage data for wine storage tanks.

Wine storage tanks have sustained earthquake damage in a number of past earthquakes worldwide (see [29-35]), but damage information has generally not been statistically documented following these earthquakes. One of the most significant earthquakes that caused substantial damage to wine

1 Corresponding Author, PhD Student, Department of Civil and Environmental Engineering, The University of Auckland, Auckland, New Zealand, Email (myaz864@aucklanduni.ac.nz)

2 Professor, Department of Civil and Environmental Engineering, The University of Auckland, Auckland, New Zealand (Fellow)

3 Managing Director, Diagnostics- Walter P Moore, Los Angeles, USA

4 Landscape Governance \& Policy, Manaaki Whenua - Landcare Research, Lincoln, NZ

5 Faculty of Environment, Society and Design, Lincoln University, Lincoln, New Zealand

6 Senior Research Fellow, Department of Civil and Environmental Engineering, The University of Auckland, Auckland, New Zealand 
tanks was the $2010 \mathrm{M}_{\mathrm{w}} 8.8$ earthquake in Chile, where more than $75 \%$ of total financial loss within one of the inspected wineries was due to lost wine because of damaged wine tanks and the remaining $25 \%$ of losses was mostly due to structural damage to stainless-steel wine storage tanks [36].

To address this lack of a comprehensive earthquake damage database for wine storage tanks, the study reported herein introduces a comprehensive damage database for wine storage tanks based on post-earthquake damage assessment data collected following recent earthquakes in New Zealand.

\section{AND 2016 EARTHQUAKES IN NEW ZEALAND}

In July and August of 2013 a series of earthquakes occurred in the Cook Strait region of New Zealand. The first sequence commenced on 19 July 2013 with a $\mathrm{M}_{\mathrm{w}} 5.5$ earthquake centred $30 \mathrm{~km}$ east of Seddon. This event was followed by two more severe events, being the $M_{w} 6.5$ Seddon earthquake on 21 July centred $25 \mathrm{~km}$ east of Seddon at a depth of $13 \mathrm{~km}$ and the $\mathrm{M}_{\mathrm{w}}$ 6.6 Lake Grasmere earthquake on 16 August 2013 centred $10 \mathrm{~km}$ southeast of Seddon at a depth of $8 \mathrm{~km}$ [7]. For simplicity, this sequence of earthquake events is referred to as the "2013 earthquakes" in the subsequent discussions.

The epicentre of the $2016 \mathrm{M}_{\mathrm{w}} 7.8$ Kaikōura earthquake was located $15 \mathrm{~km}$ northeast of Culverden (a small town located in the northern Canterbury region of New Zealand's South Island) at a depth of $15 \mathrm{~km}$ [37], with intense shaking occurring for approximately two minutes at just after midnight and with aftershocks occurring across a complex connected series of faults in the Marlborough Fault System [38]. For simplicity the Kaikoura earthquake event is referred to as the "2016 earthquake" in the subsequent discussions.

The earthquakes in 2013 and 2016 affected the Marlborough region and led to the initiation of new research to investigate the vulnerability of elements within wineries, see [4-7], and [3941]. The effects of these recent earthquakes demonstrated that the New Zealand wine industry continues to be vulnerable to seismic hazards, with observations showing that wine storage tanks sustained the majority of the reported damage.

\section{BACKGROUND OF NZSEE RECOMMENDATIONS FOR DESIGN OF STORAGE TANKS}

In 1986 NZSEE [42] published a guideline for the seismic design of storage tanks, which was later updated in 2009 [43] There is no definitive data showing the percentage of wine storage tanks in Marlborough that were designed based on the 1986 or 2009 versions of NZSEE, but the approximate data published in the literature [7] and practical advice from industry representatives suggests that while the guidelines were used in the design of many of these tanks, there were some cases where the guidelines were not followed at all. According to the fabrication date collected in 2013 for 567 wine tanks from one of these wineries, $44 \%$ (247) of the wine tanks were fabricated before 1986 while $56 \%$ (320) of the wine tanks in that winery were fabricated between 1986 and 2009. Au et al. [41] recommended that while the NZSEE guidelines [43] provides comprehensive guidance for the design of liquid storage tanks, the document must be used with caution when applied to the design of stainless-steel cylindrical wine storage tanks. Catwalks are another element in the wineries that are used to provide access to the top of the tank for various wine making and maintenance tasks and are typically designed as two types: (i) self-supported; (ii) tank-supported. The NZSEE guidance [43] does not provide information on the design of catwalks and their connection to wine storage tanks.

\section{METHODOLOGY OF DAMAGE DATA COLLECTION AND ANALYSIS}

Competent structural engineers inspected the exterior and interior of individual wine tanks in 7 major wineries following the 2013 earthquakes and in 5 major wineries following the 2016 earthquake. Table 1 shows the total number of tanks that were inspected during the site visits to wineries in the 2013 and 2016 earthquakes. During each of the winery site inspections, photographs documenting the extent and type of damage to each part of the tanks were captured for each individual tank. In the 2013 earthquakes damage data were categorised into three groups: (i) minor; (ii) moderate; (iii) major and in the 2016 earthquake the damage to wine tanks was defined based on the required repairs that winery stakeholders needed to follow (see Table 2).

Wine tanks within the inspected wineries sustained different level of damage due to variations in their tank inventory and experienced peak ground acceleration (PGA) levels (see Table 3). Shakemap [44] and Seisfinder [45] were used to quantify the PGA that each of the wineries sustained during the 2013 and 2016 earthquakes respectively.

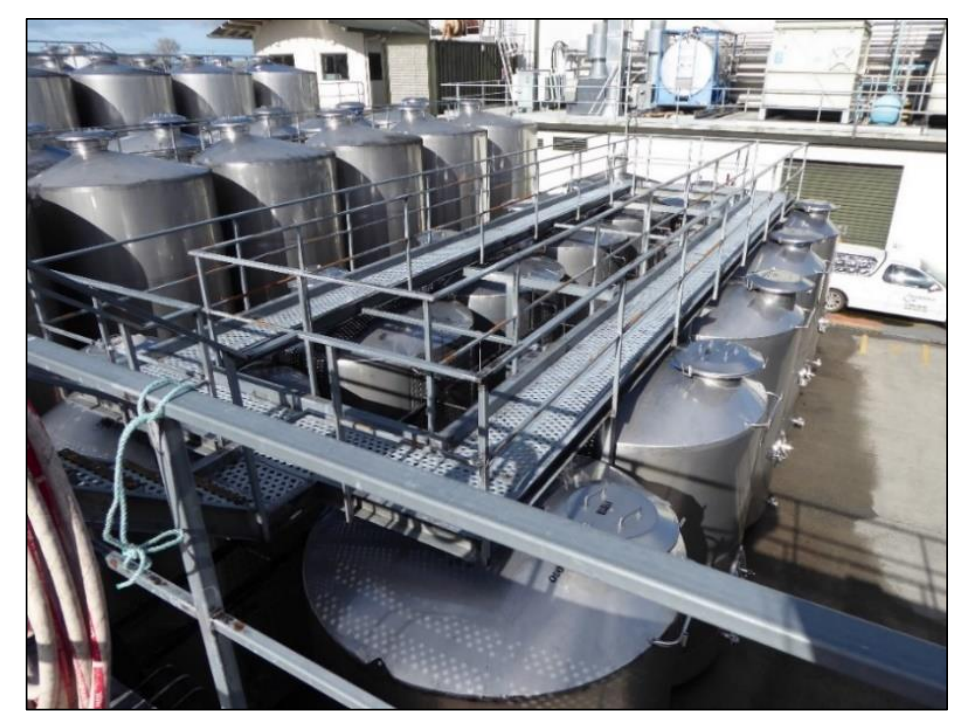

Figure 1: Typical example of catwalks used in New Zealand wineries. 


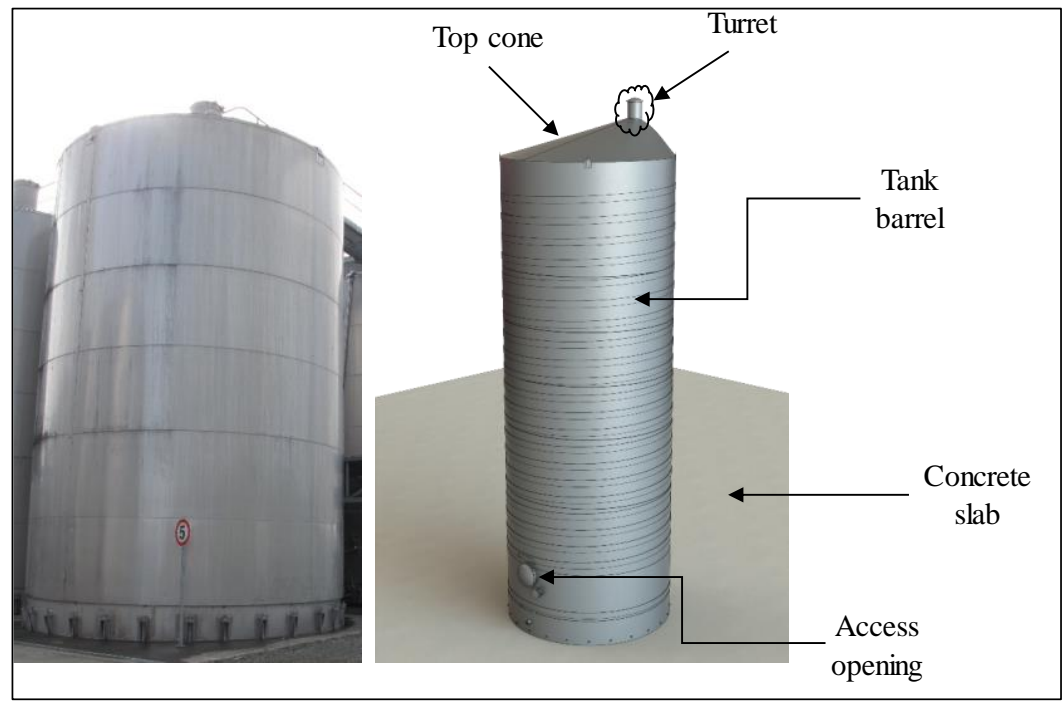

(a) Different parts of a typical flat-based tank

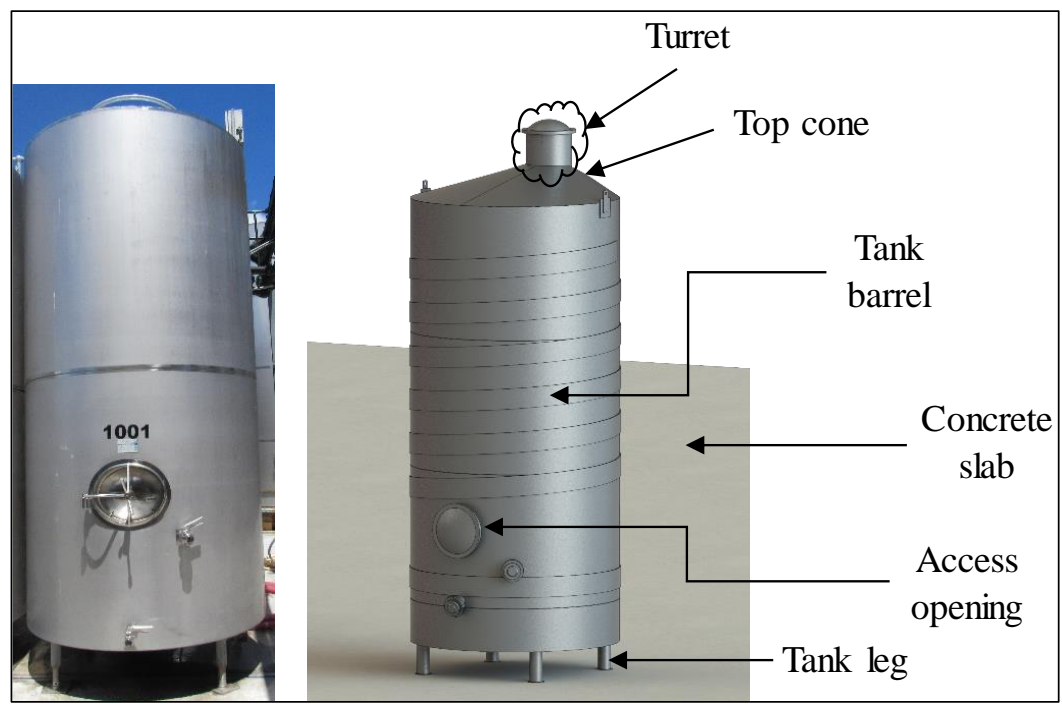

(b) Different parts of a typical legged tank

Figure 2: Example of two typical tank types observed in New Zealand wineries.

Table 1: Tank database used in the present study.

\begin{tabular}{|c|c|c|c|}
\hline Earthquake names & $\begin{array}{c}\text { Number of flat-based } \\
\text { tanks }\end{array}$ & $\begin{array}{c}\text { Number of legged } \\
\text { tanks }\end{array}$ & $\begin{array}{c}\text { Overall number of } \\
\text { tanks }\end{array}$ \\
\hline $\begin{array}{c}2013 \mathrm{M}_{\mathrm{w}} \text { 6.5 Seddon and } \\
\mathrm{M}_{\mathrm{w}} 6.6 \text { Lake Grassmere } \\
\text { earthquakes }\end{array}$ & 546 & 1512 & 2058 \\
\hline $2016 \mathrm{M}_{\mathrm{w}} 7.8$ Kaikōura & 802 & 599 & 1401 \\
\hline
\end{tabular}


Table 2: Damage definition for wine storage tanks following the 2016 earthquake.

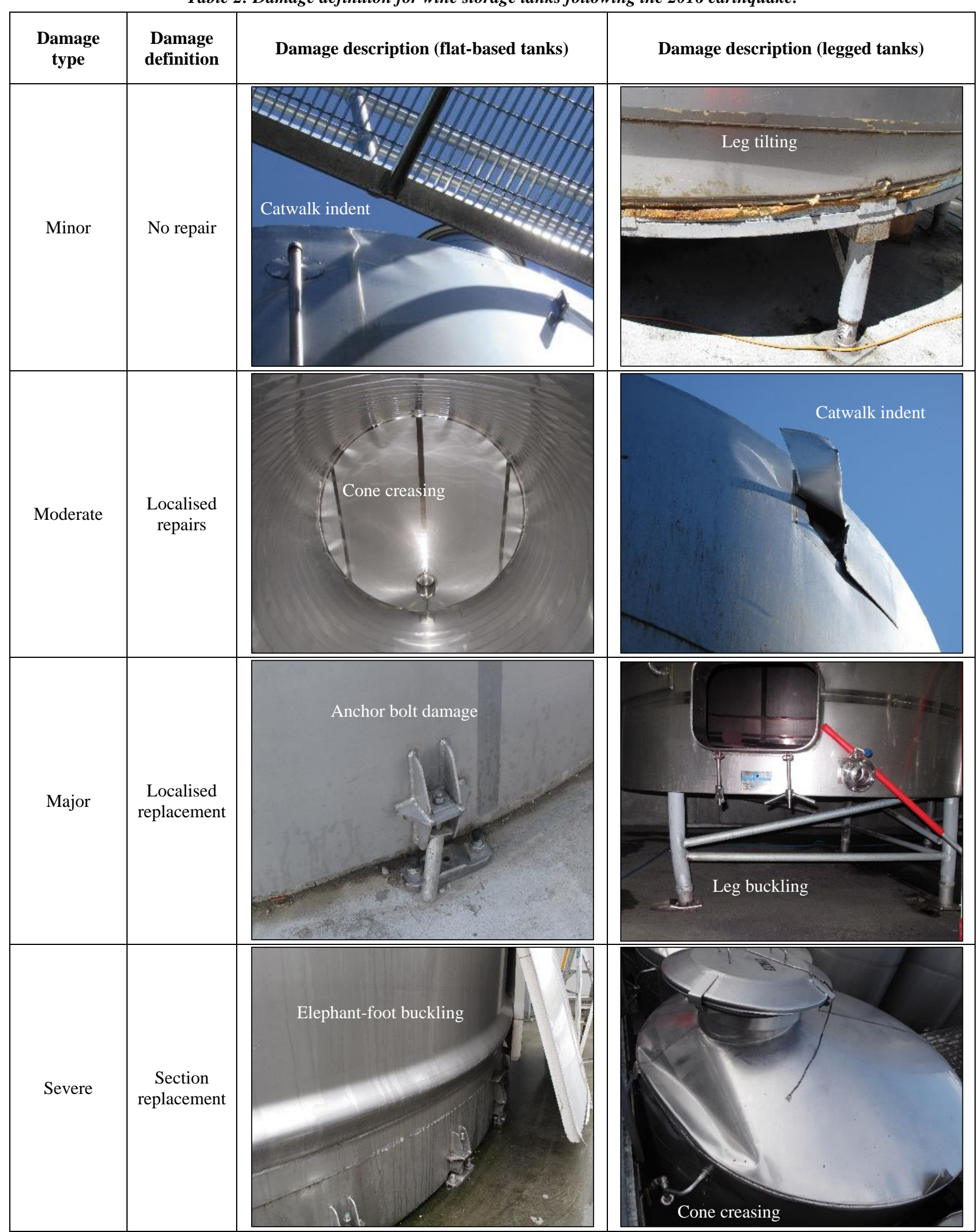




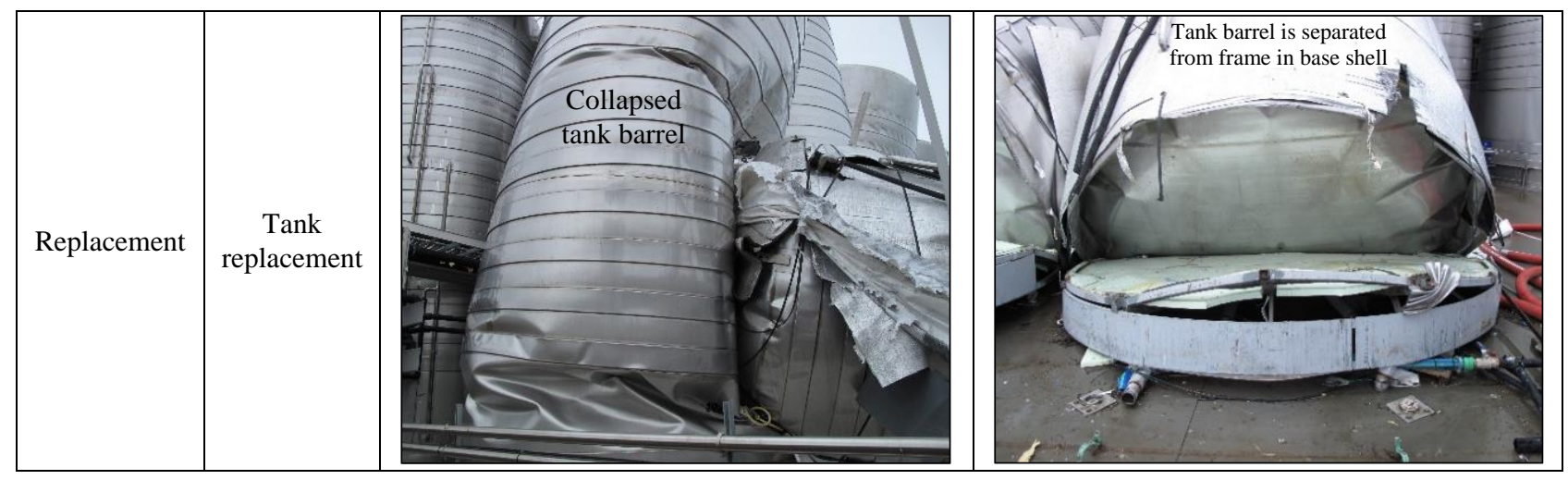

Table 3: Tank inventory data and experienced PGA for each winery reported in the present study.

\begin{tabular}{|c|c|c|c|c|c|}
\hline $\begin{array}{c}\text { Earthquakes } \\
\text { name }\end{array}$ & $\begin{array}{l}\text { Winery } \\
\text { ID }\end{array}$ & No. of tanks & Damaged tanks & $\begin{array}{c}\text { PGA } \\
{[\mathrm{g}]}\end{array}$ & PGA source \\
\hline \multirow{7}{*}{$\begin{array}{c}2013 \mathrm{M}_{\mathrm{w}} 6.5 \\
\text { Seddon and } \mathrm{M}_{\mathrm{w}} \\
6.6 \text { Lake } \\
\text { Grassmere } \\
\text { earthquakes }\end{array}$} & (1)-2013*** & 163 & 130 & 0.11 & \multirow{7}{*}{ Shakemap* [44] } \\
\hline & (2) & 110 & 45 & 0.12 & \\
\hline & (3) & 276 & 203 & 0.20 & \\
\hline & (4)-2013*** & 229 & 202 & 0.40 & \\
\hline & (5) & 577 & 302 & 0.21 & \\
\hline & (6) & 270 & 105 & 0.20 & \\
\hline & (7) & 433 & 176 & 0.20 & \\
\hline \multirow{5}{*}{$\begin{array}{c}2016 \mathrm{M}_{\mathrm{w}} 7.8 \\
\text { Kaikōura }\end{array}$} & (1)-2016*** & 265 & 141 & 0.32 & \multirow{5}{*}{ Seisfinder**[45] } \\
\hline & 8 & 405 & 212 & 0.26 & \\
\hline & 9 & 213 & 116 & 0.32 & \\
\hline & (4)-2016*** & 299 & 260 & 0.36 & \\
\hline & 10 & 219 & 171 & 0.23 & \\
\hline
\end{tabular}

*https://earthquake.usgs.gov/data/shakemap/

**https://quakecoresoft.canterbury.ac.nz/seisfinder/search

***Wineries (1) and (4) were inspected in both the 2013 and 2016 earthquakes

\section{OVERVIEW OF ANALYSIS OF COLLECTED EARTHQUAKE DAMAGE DATA}

\section{Flat-based Tanks}

Typical examples of damage to flat-based tanks and the percentage of each damage type in the tank inventory can be seen in Figure 3. Figure $4 a, b$ shows that although wineries sustained typically lower PGA levels in the 2013 earthquakes, flat-based tanks sustained slightly more damage in the 2013 earthquakes $(73 \%, 404$ out of 546 tanks) when compared with the 2016 earthquake $(69 \%, 557$ out of 802 tanks). This reduction in damage percentage occurred because following the substantial losses during the 2013 earthquakes, winery operators started to account for earthquake resilience in their short-term and long-term planning as well as undertaking repair/replacement of severely damaged tanks [8]. One example of the earthquake resilience measures that were introduced after the 2013 earthquakes was the implementation of new foundation anchorage systems involving energy dissipation devices (see Figure 5), with analysis of post-earthquake damage data following the 2016 earthquake revealing that these energy dissipation devices performed well. Based on a research study conducted by Yazdanian et. al [35], energy dissipation devices performed well with the least extent of reported earthquake related damage.

Tank capacity was a parameter that had a significant influence on the extent of damage to flat-based wine tanks (see Figure $6 a, b)$. In the 2013 earthquakes $90 \%$ of tanks with capacities of between $100 \mathrm{~kL}$ to $300 \mathrm{~kL}$ sustained damage, and there is a marked difference in character between the earthquake damage data for tanks with a capacity below $100 \mathrm{~kL}$ when compared with data for tanks having a capacity of between $100 \mathrm{~kL}$ and $300 \mathrm{~kL}$. Tanks with a capacity of $20-40 \mathrm{~kL}$ and $40-60 \mathrm{~kL}$ sustained $67 \%$ and $53 \%$ damage respectively in the 2013 earthquakes. Also, 59\% (13 out of 22 tanks) of flat-based wine tanks with a capacity of greater than $300 \mathrm{~kL}(400 \mathrm{~kL}$ and $550 \mathrm{~kL}$ tanks) sustained damage (see Figure 6a). All of these $400 \mathrm{~kL}$ and $550 \mathrm{~kL}$ tanks had a low height to radius (H/R) aspect ratio, were not anchored to their foundation, sustained no to minor damage (see Figure 8), and continued to operate following the 2013 earthquakes.

Wine tanks are typically slender with a high $\mathrm{H} / \mathrm{R}$ aspect ratio of between 3 to 5 , which makes them vulnerable to buckling and overturning failure modes in particular when subjected to large intensity earthquake shaking [41]. Due to aspects of the wine making process such as cooling and refrigeration, wine makers prefer to use slender wine tanks (see Figure 9) although no slender wine tank having a capacity greater than $300 \mathrm{~kL}$ were seen within the collected inventory. Flat-based wine tanks with large capacities of $400 \mathrm{~kL}$ and $550 \mathrm{~kL}$ (see Figure 8) that performed well following the 2013 earthquakes had a similar geometry to that of typical low aspect ratio cylindrical steel water tanks. Several cylindrical steel water tanks within one of the wineries were also inspected during the winery inspection following 2013 earthquakes, with inspections revealing no major damage to these large volume water tanks. Note that the data presented herein is limited to wine storage tanks and that damage data for water tanks from the inspected wineries is not reported in this research.

In the 2016 earthquake inspected flat-based wine tanks with a volume of between $20-40 \mathrm{~kL}$ sustained the largest extent of 
damage among all ranges of tank capacity, with $83 \%$ of 20 $40 \mathrm{~kL}$ tanks having been damaged. During the site inspections following the 2016 earthquakes it was identified that following the 2013 earthquakes, winery operators placed emphasis on strengthening of larger capacity wine tanks by using new energy dissipation devices, leaving smaller wine tanks mostly with outdated anchorage systems (see Figure 7).

\section{Damage Data on Different Parts of Flat-based Tanks}

Critique of collected damage data following the 2013 earthquakes revealed that the anchor (47\% of 546 tanks) and tank base shell (39\% of 546 tanks) parts of flat-based wine tanks sustained the largest percentage of damage, while in the 2016 earthquake the number of tanks with damage to their anchors and tank base shells reduced to $23 \%$ and $32 \%$. In the 2016 earthquake, damage to the barrel (54\% of 802 tanks) and cone (43\% of 802 tanks) parts of the flat-based tanks had the largest percentage of damage when compared to different parts of flatbased tanks that sustained damage (see Figure 10a,b).

Different damage types that caused damage to the barrel parts of tanks in both the 2013 and 2016 earthquakes are shown in Figure 11a,b. Catwalk indenting was the most frequent damage type that caused substantial damage to barrel parts of flat-based wine tanks in both the 2013 and 2016 earthquakes, where
$10.0 \%$ and $24.4 \%$ of flat-based tanks in the 2013 earthquakes and the 2016 earthquake sustained damage to the barrel due to catwalk indenting (see Figure 11a,b).

Elephant-foot buckling (see Figure 3i) generally occurs in tanks that are mostly fully filled, is an elastic-plastic type of instability [43], [46], [16], and can be described as an outward bulge of the tank wall shell, whereas diamond shaped buckling (see Figure 3h) is a type of elastic instability [43], [46], [16]. Sobhan et al. [46] stated that elephant-foot buckling of the steel tank wall is caused by the interaction of both circumferential tensile stress close to the yield strength and by axial compressive stress exceeding the critical stress, whilst diamond shaped buckling is caused by severe axial compressive stresses. Compared with the 2013 earthquakes, in the 2016 earthquake larger percentages of elephant foot buckling and diamond shaped buckling were observed, with earthquake elephant-foot buckling (11.0\%) and diamond shaped buckling (6.1\%) causing the highest percentage of severe (section replacement) damage to the barrel.

A vast majority of the anchors having earthquake-related damage (94\%) in the 2016 earthquake required replacement (see Figure 12a,b). Bolt buckling (see Figure 3a) and bolt elongation (see Figure 3d) were the most common types of failure mode observed in both the 2013 and 2016 earthquakes.

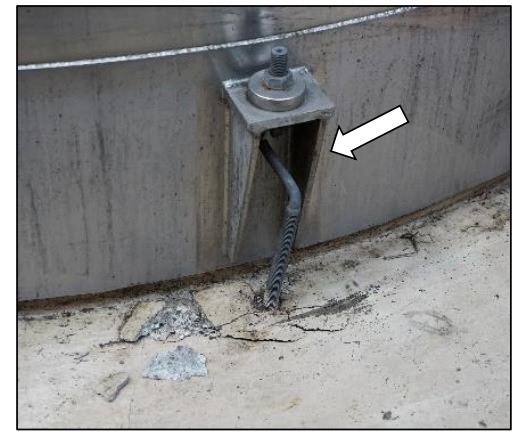

(a) Bolt buckling: $6.1 \%$ in 2016

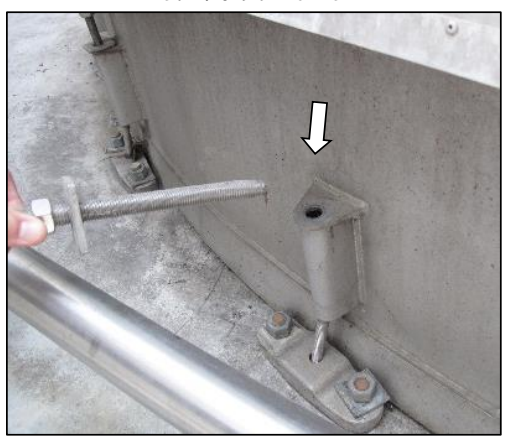

(d) Bolt elongation: $7.4 \%$ in 2016

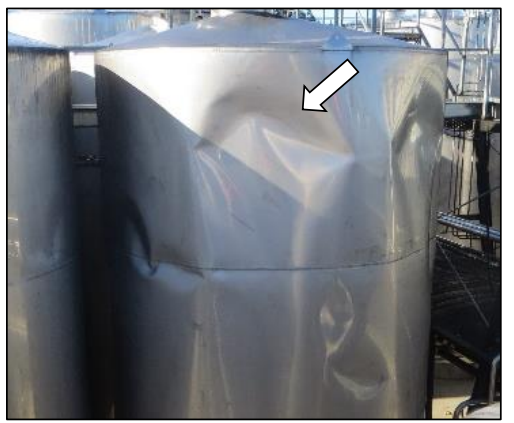

(g) Barrel other:

$2.6 \%$ in 2013 (14.7\% in 2016)

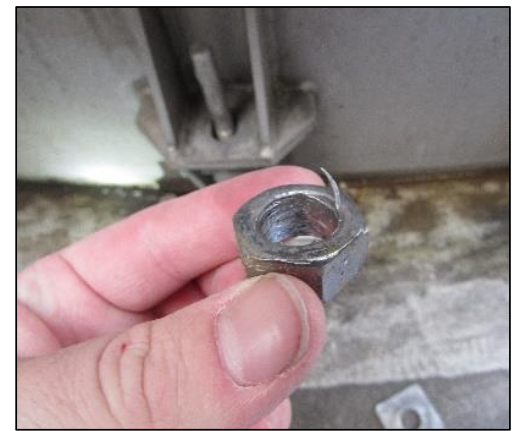

(b) Thread shearing:

$7.5 \%$ in 2013 (4.0\% in 2016)

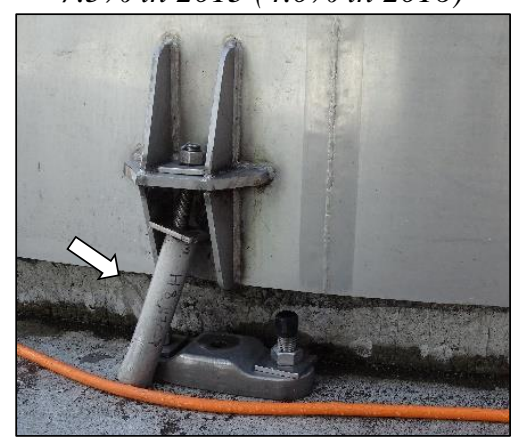

(e) Displaced anchor: $1.0 \%$ in 2016

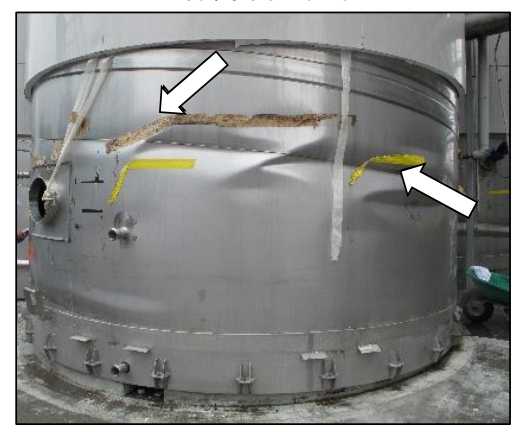

(h) Diamond shaped buckling: $1.0 \%$ in 2013 (6.1\% in 2016)

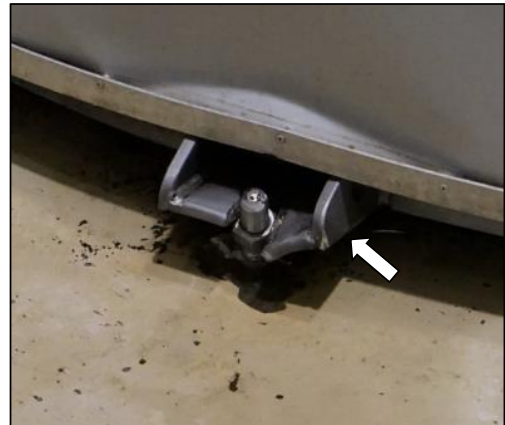

(c) Bracket failure: $1.0 \%$ in 2016

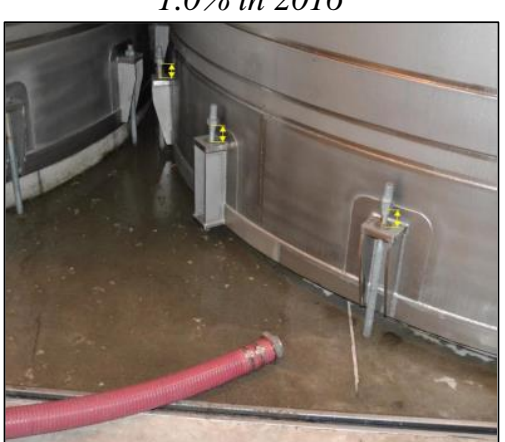

(f) Tank settlement:

$20.0 \%$ in 2013

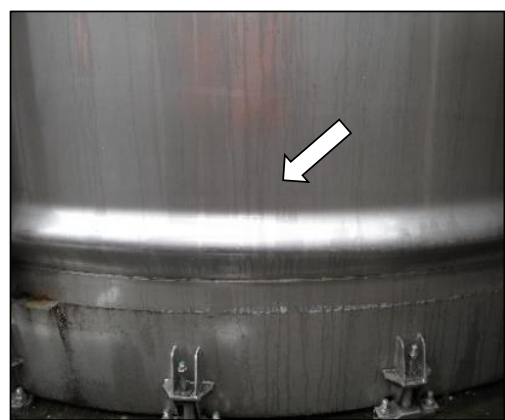

(i) Elephant foot buckling:

$6.2 \%$ in 2013 (11.0\% in 2016)

Figure 3 (Continued): Typical damage types to flat-based tanks with percentage of each damage type. 


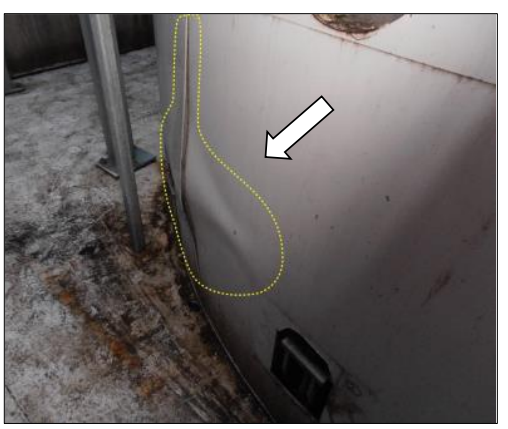

(j) Barrel insulation damage: $13 \%$ in 2016

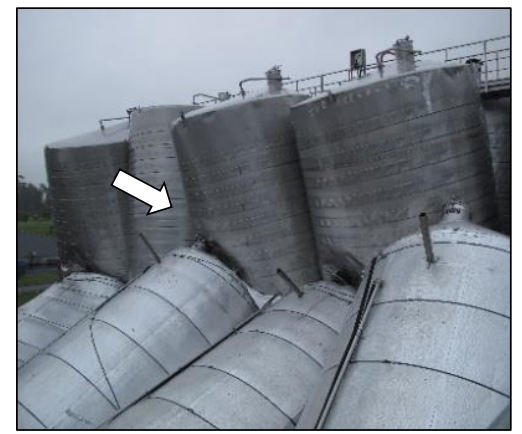

(m) Tank pounding (Barrel): $3.1 \%$ in 2013 (4.4\% in 2016)

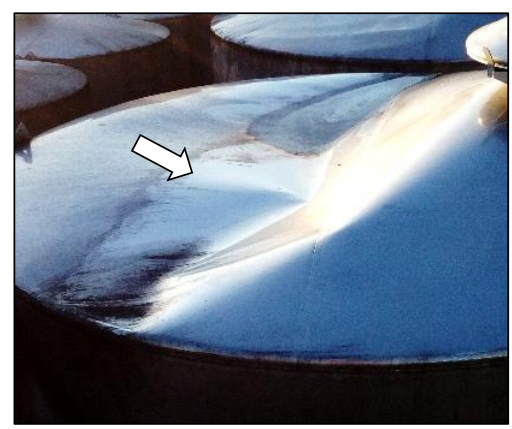

(k) Cone damage:

$14 \%$ in 2013 (43\% in 2016)

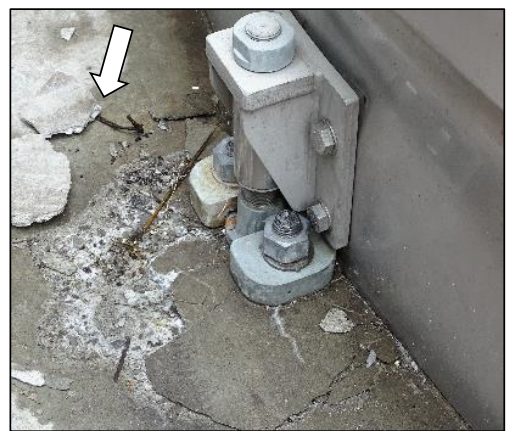

(o) Foundation damage: $14 \%$ in 2013 (11\% in 2016)

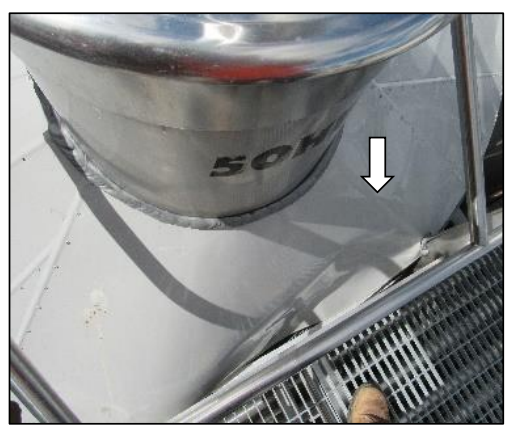

(l) Catwalk indent (barrel): $10 \%$ in 2013 (24.4\% in 2016)

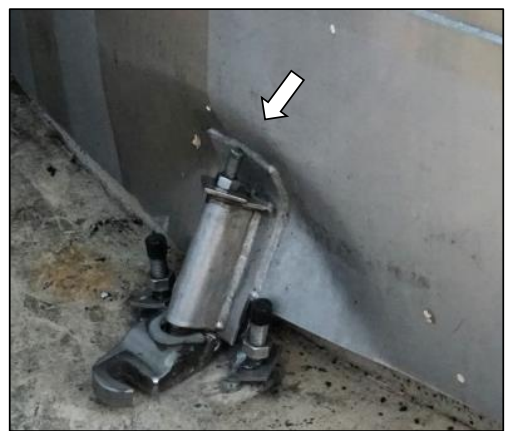

Skirt damage:

$2 \%$ in 2013 (16\% in 2016)

Figure 3: Typical damage types to flat-based tanks with percentage of each damage type.

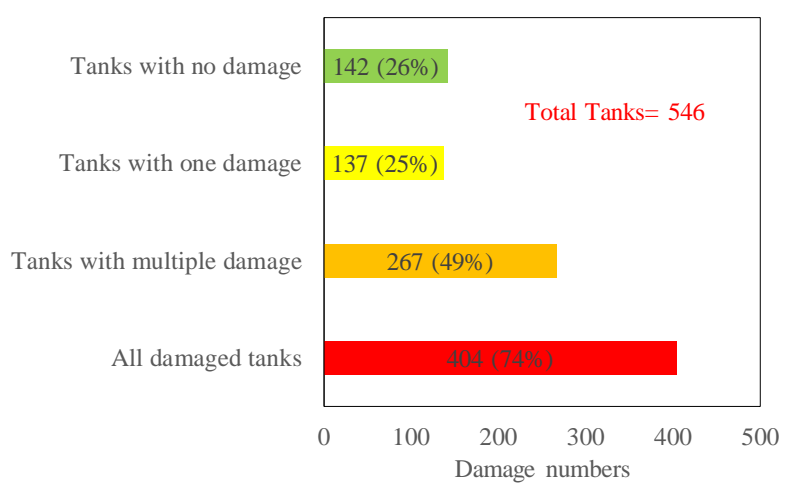

(a) 2013 earthquakes

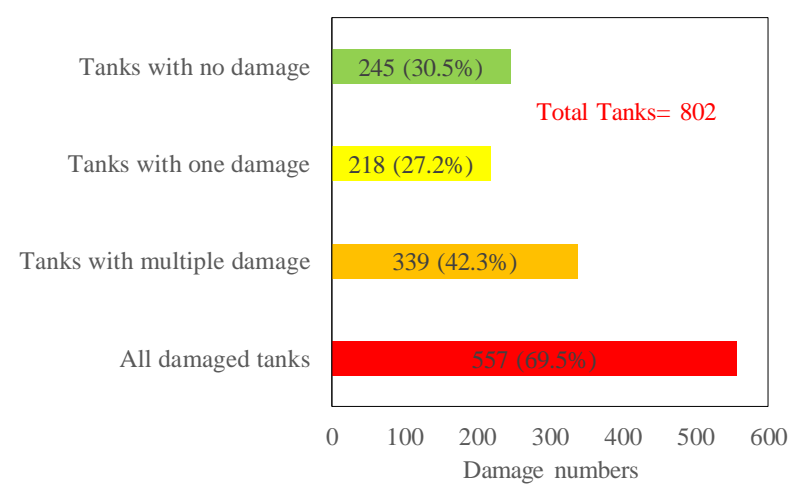

(b) 2016 earthquake

Figure 4: Summary of damage to flat-based tanks. 


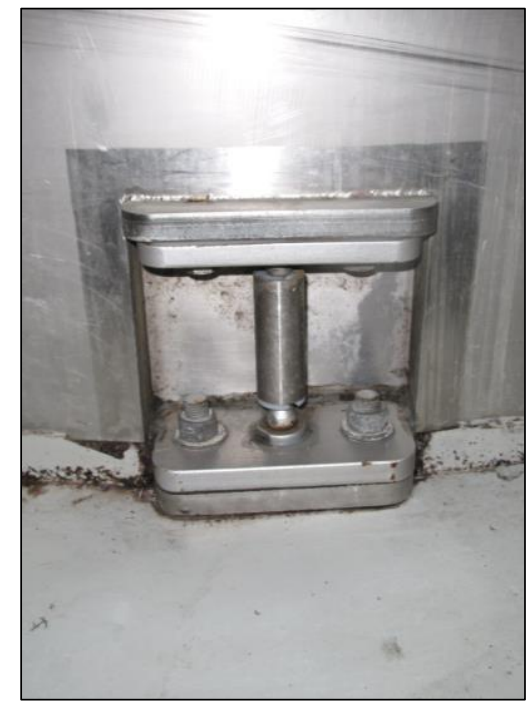

(a) Energy dissipation devices used for anchoring $40 \mathrm{~kL}$ tank

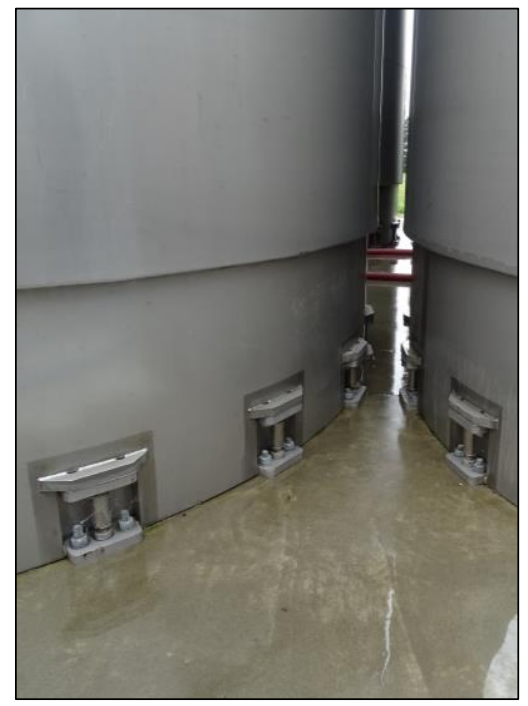

(b) Energy dissipation devices used for anchoring $120 \mathrm{~kL}$ tank

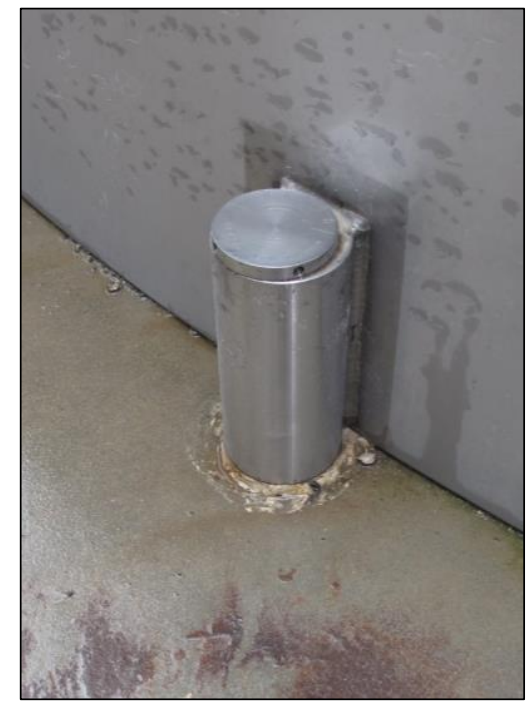

(c) Energy dissipation devices used for anchoring $240 \mathrm{~kL}$ tank

Figure 5: Examples of energy dissipation devices used in wineries with no damage after 2016 Kaikōura earthquake.

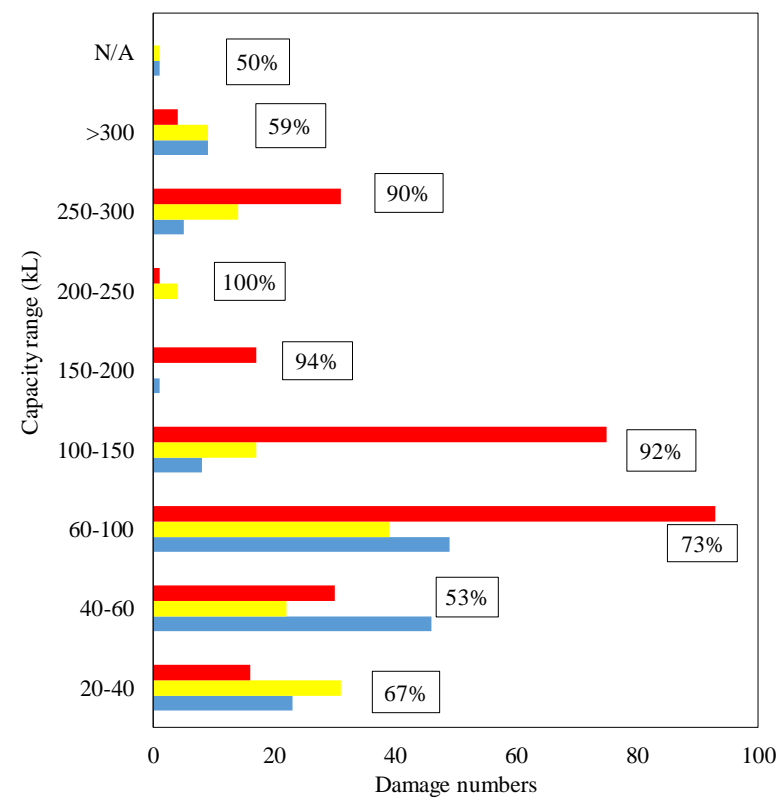

- Tanks with multiple damage $₫$ Tanks with one damage $=$ Tanks with no damage

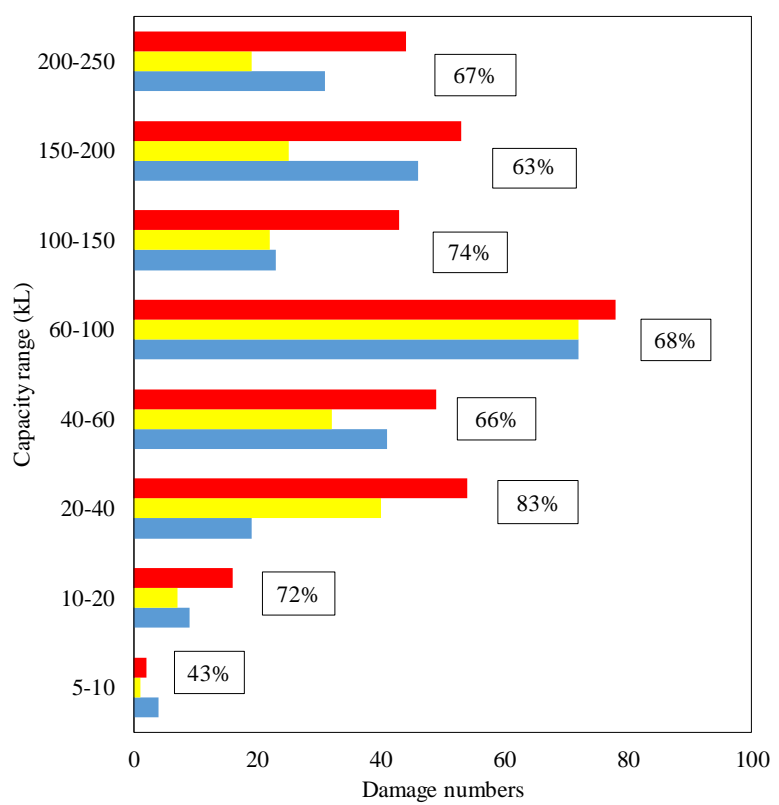

- Tanks with multiple damage $=$ Tanks with one damage $=$ Tanks with no damage

(a) 2013 earthquakes

(b) 2016 earthquake

Figure 6: Damage percentage to flat-based tanks based on tank capacity range.

(Note: \% in the figures relates to the total percentage of damaged tanks for that capacity range) 


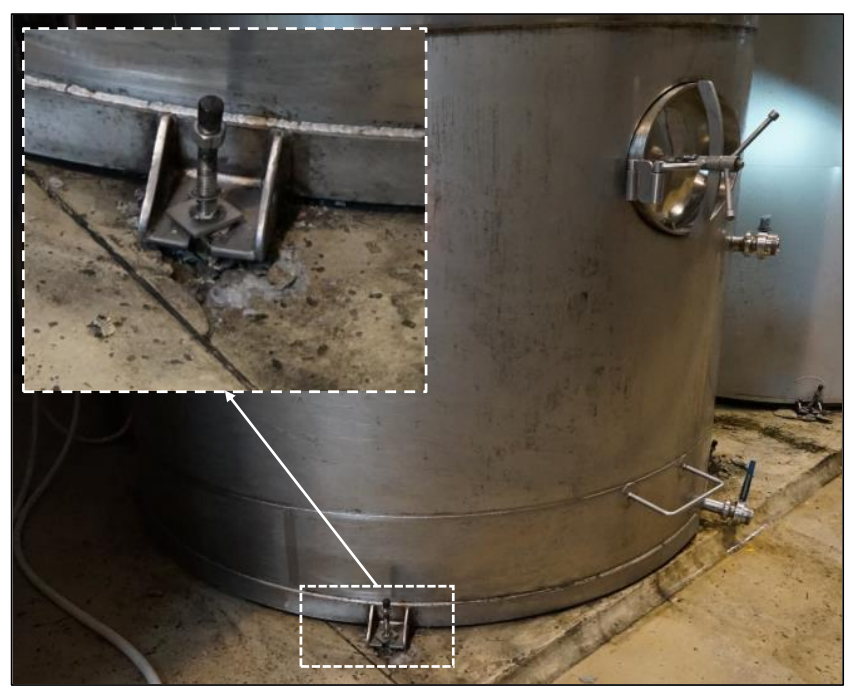

(a) Loose bolt due to seismic loads with minor damage to concrete slab

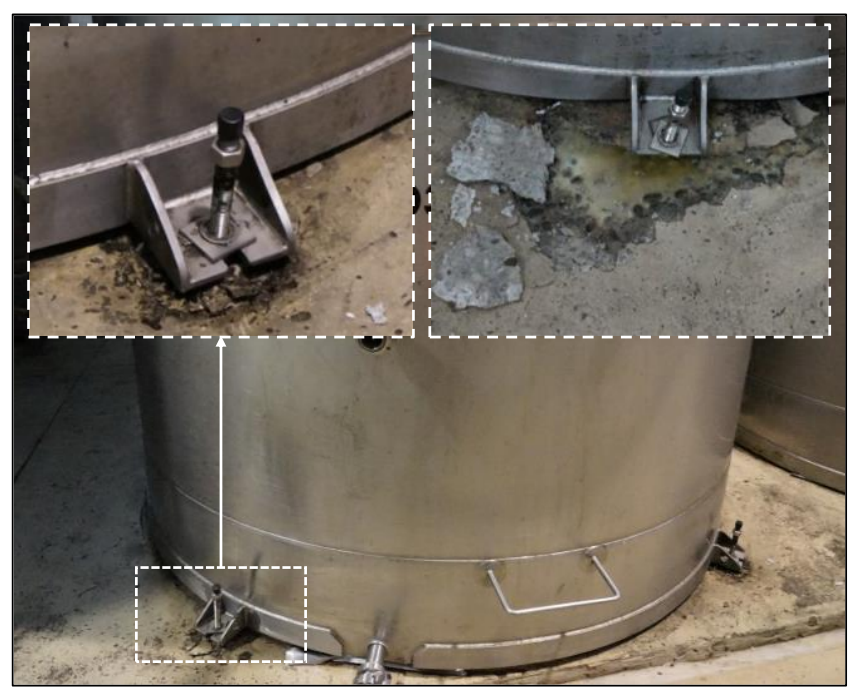

(c) One loose bolt resulted in damage to the concrete slab and the other loose bolt caused no visible damage to the concrete slab

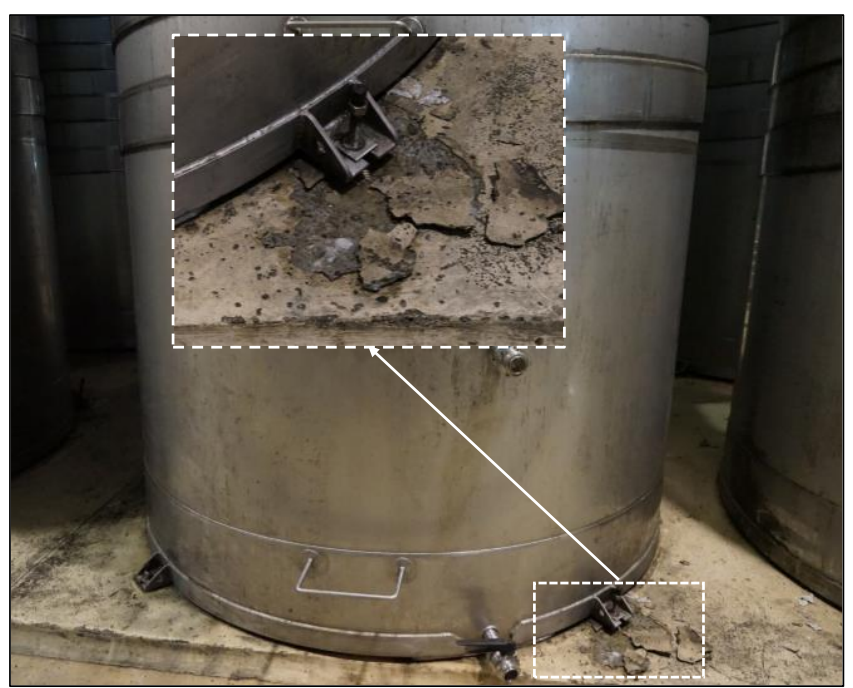

(b) Loose bolt resulted in severe damage to concrete slab

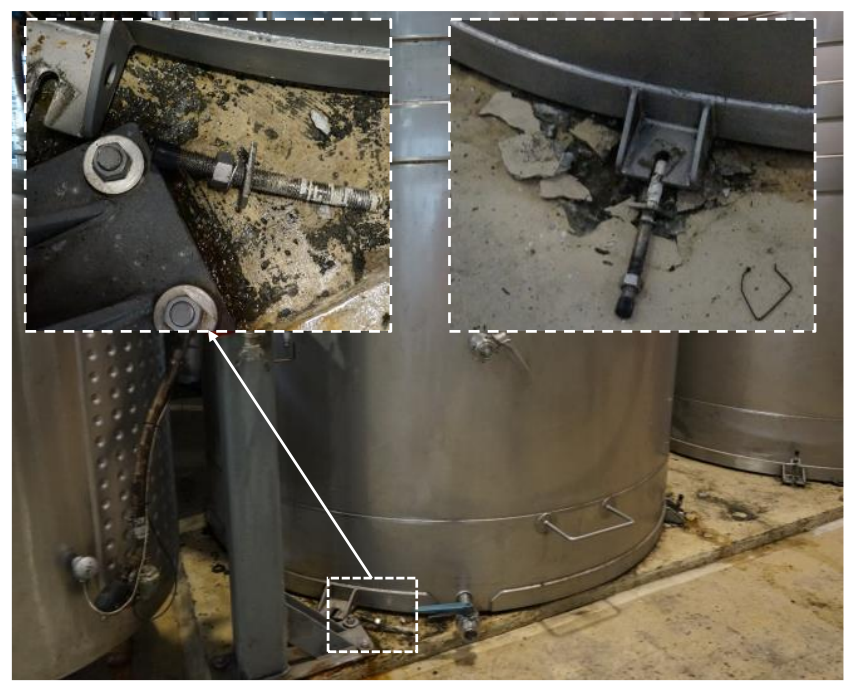

(d) Anchor pull-out and slab damage

Figure 7: Damaged 25 kL flat-based wine tanks due to simplicity of the anchorage system.

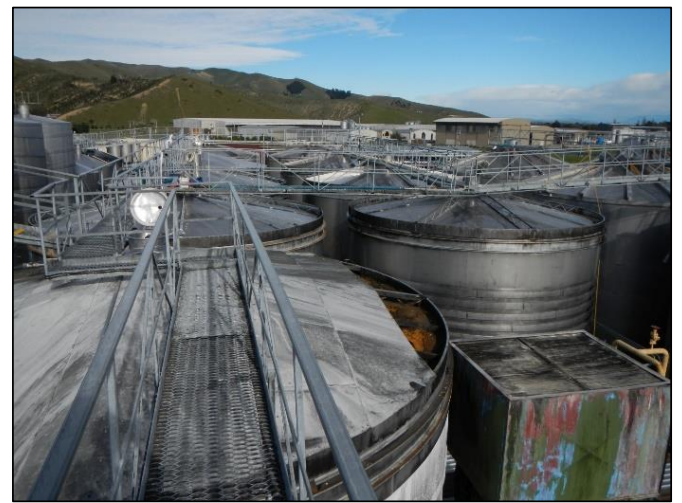

(a) Tank $400 \mathrm{~kL}$

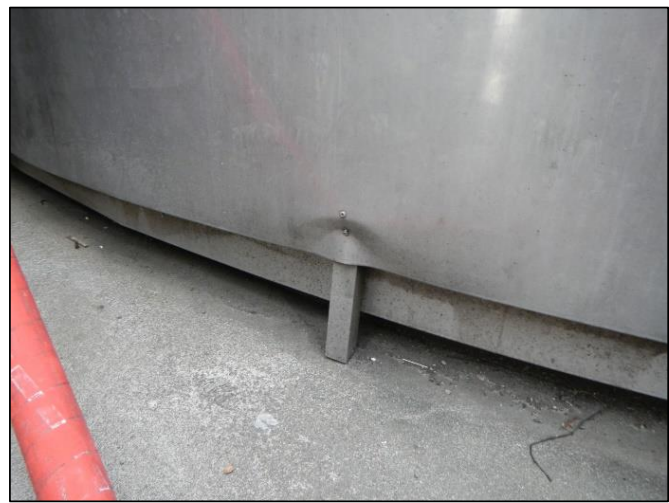

(b) Tank $400 \mathrm{~kL}$ - minor damage to the skirt

Figure 8 (Continued): Examples of wine tanks with low aspect ratio and large capacity of $400 \mathrm{~kL}$ and $550 \mathrm{~kL}$. 


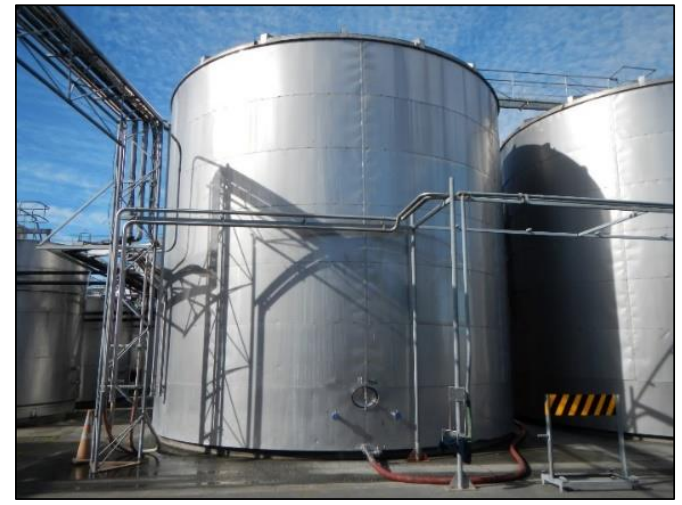

(c) $550 \mathrm{~kL} \mathrm{tank}$

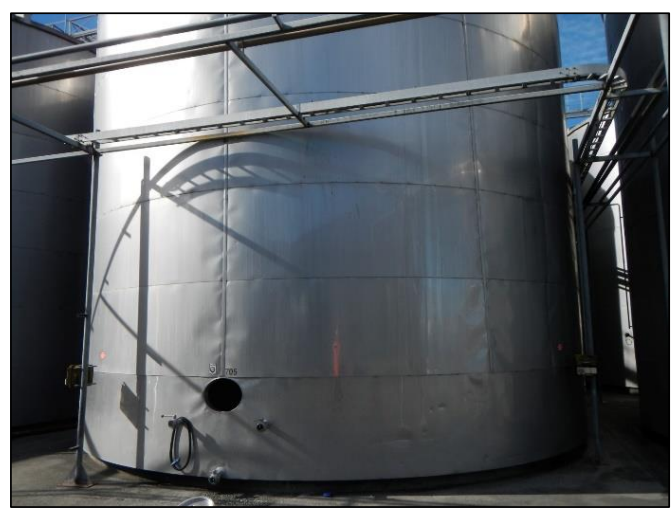

(d) $550 \mathrm{~kL}$ tank - minor damage to the barrel

Figure 8: Examples of wine tanks with low aspect ratio and large capacity of $400 \mathrm{~kL}$ and $550 \mathrm{~kL}$.

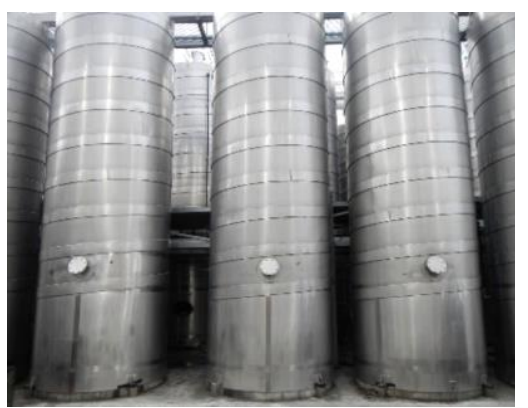

(a) Tanks of unknown tank capacity, after 2013 earthquakes

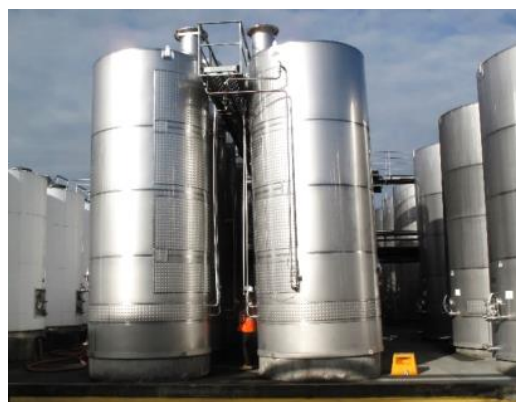

(b) $150 \mathrm{~kL}$ tanks, after 2016 earthquake

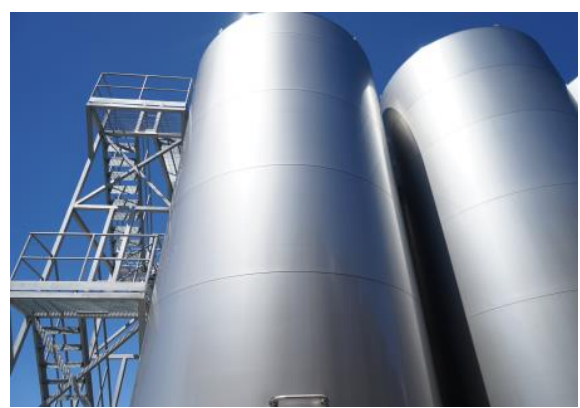

(c) 90 kL tanks, after 2016 earthquake

Figure 9: Examples of typical slender wine tanks with high aspect ratio observed within the wineries.

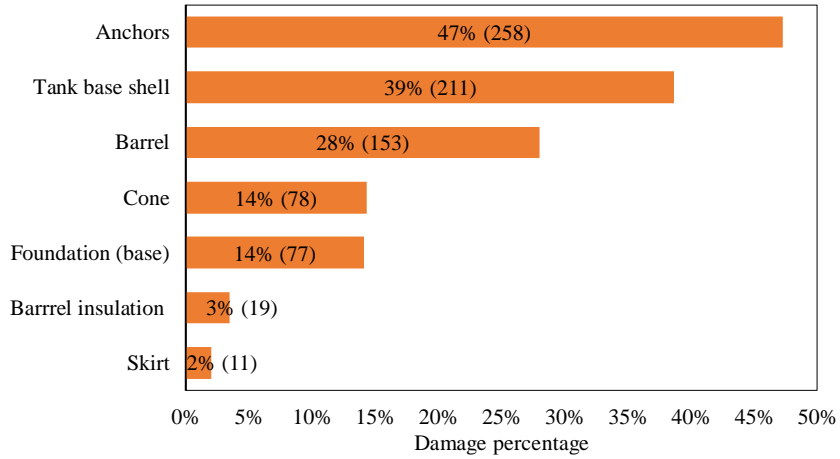

(a) 2013 earthquakes

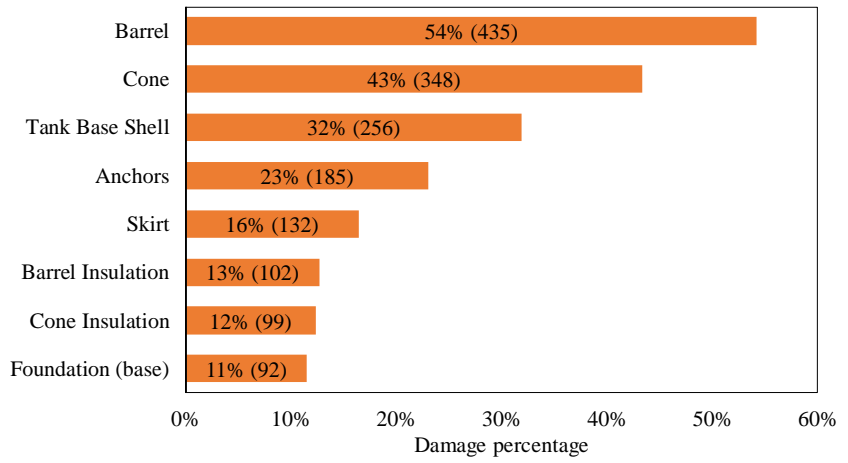

(b) 2016 earthquake

Figure 10: Percentage of damage to different parts of flat-based tanks.

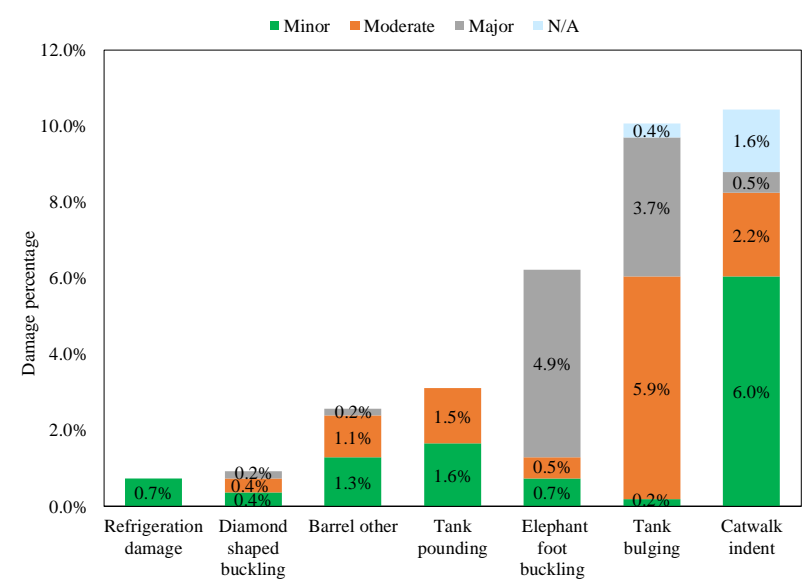

(a) 2013 earthquakes

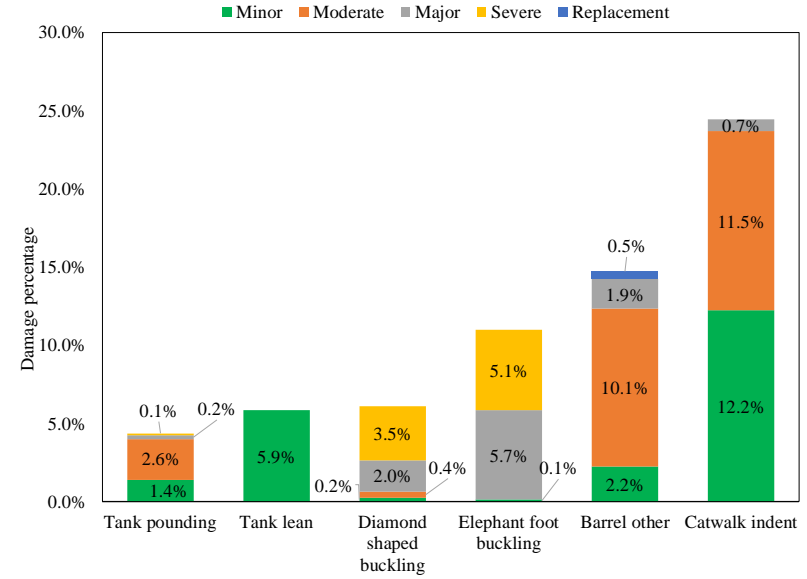

(b) 2016 earthquake

Figure 11: Percentage of different failure modes that caused damage to barrel parts of flat-based tanks. 


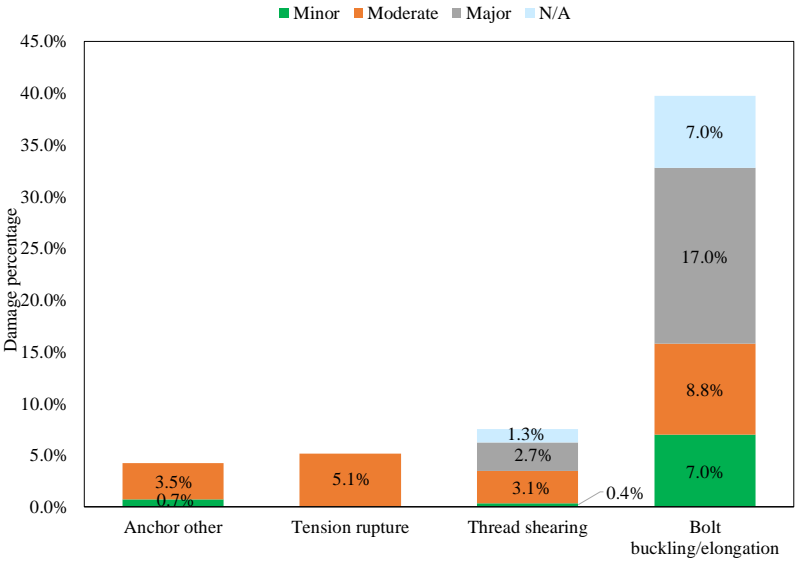

(a) 2013 earthquakes

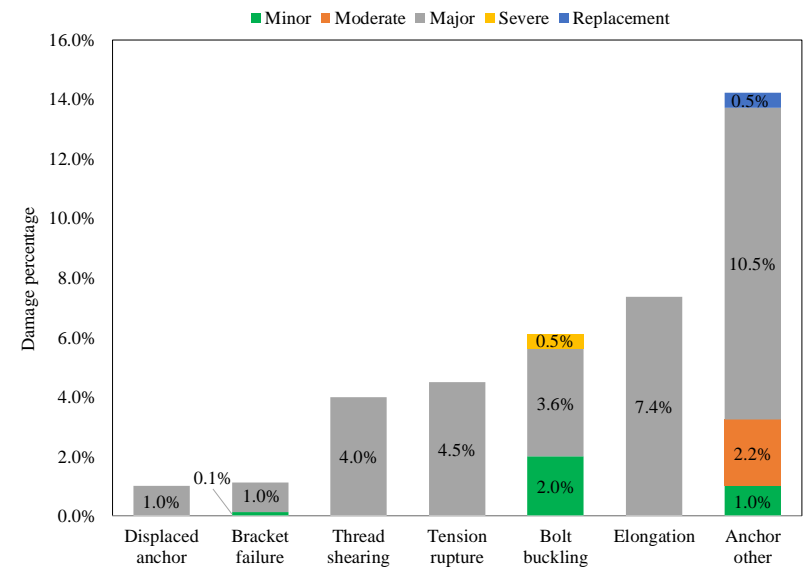

(b) 2016 earthquake

Figure 12: Percentage of different failure modes that caused damage to anchor parts of flat-based tanks.

\section{Legged Tanks}

Examples of typical damage to legged wine tanks and the percentage of each damage type for all legged wine tanks in the inventory can be seen in Figure 13. In the 2013 earthquakes, $50 \%$ of the 1512 legged tanks in the inventory sustained damage (see Figure 14a). Also, 57\% of the 599 legged wine tanks that were inspected following the 2016 earthquake sustained damage (see Figure 14b). While results from the 2013 and 2016 earthquakes indicate that there were no consistent trends regarding correlation between the capacity of flat-based tanks and the distribution of damage levels, it can be seen in Figure $15 \mathrm{a}, \mathrm{b}$ that the percentage of damaged legged wine tanks increased with increasing tank capacity. Overall, tanks with capacities of between $60-100 \mathrm{~kL}$ sustained the largest percentage of damage amongst all legged tanks in the inventory, with $89 \%$ and $94 \%$ of tanks in this capacity range being damaged in the 2013 and 2016 earthquakes respectively.

The frames and legs of legged wine tanks sustained the highest damage percentage of the various tank elements, where $40 \%$ of 1512 legged tanks in the 2013 earthquakes and $44 \%$ of 599 legged tanks in the 2016 earthquake sustained damage to their frame or legs (see Figure 16a,b). Leg buckling $(18.5 \%$ ) and leg tilting $(10.3 \%)$ were the most frequent failure modes that caused damage to the frame or legs of legged wine tanks in the 2013 earthquakes (see Figure 17a), with the percentage of legged wine tanks having leg buckling and leg tilting reducing to $6.7 \%$ and $9.5 \%$ in the 2016 earthquake (see Figure 17b). The second most damaged element of legged wine tanks was the tank base shell, with $39 \%$ of tank base shells being damaged in the 2013 earthquakes and $43 \%$ of tank base shells being damaged in the 2016 earthquake. Approximately $68 \%$ of legged tanks that sustained base shell damage in 2016 earthquake required section replacement (see Figure 18a,b).

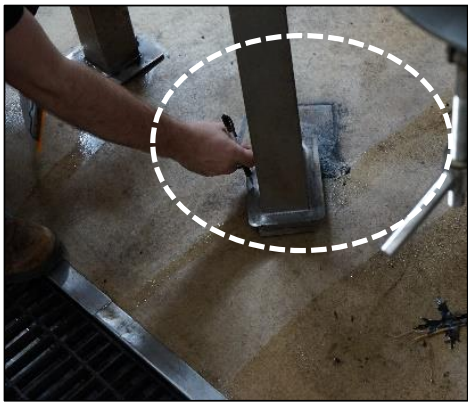

(a) Global movement: $9.3 \%$ in 2013 (2.0\% in 2016)

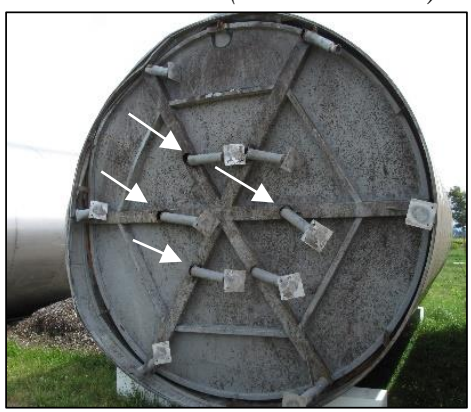

(d) Leg tilt:

$10.3 \%$ in 2013 (9.5\% in 2016)

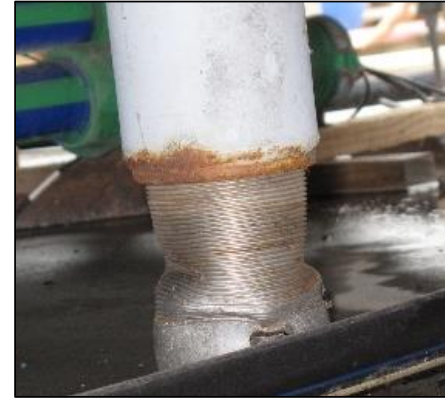

(b) Telescopic buckling: $2.8 \%$ in $2013(<1.0 \%$ in 2016)

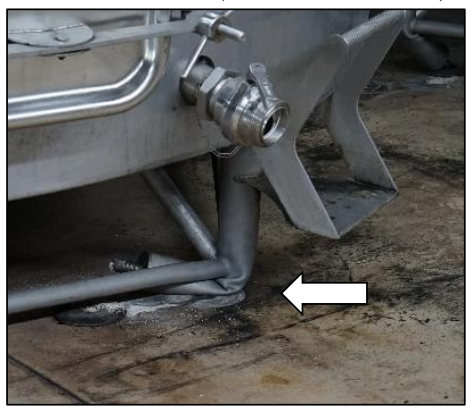

(e) Leg buckle:

$18.5 \%$ in 2013 (6.7\% in 2016)

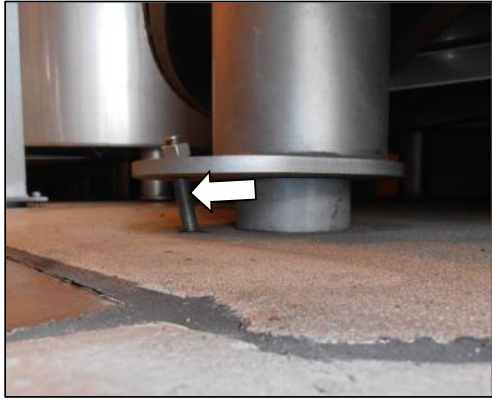

(c) Anchor bolt damage: $1.0 \%$ in 2016

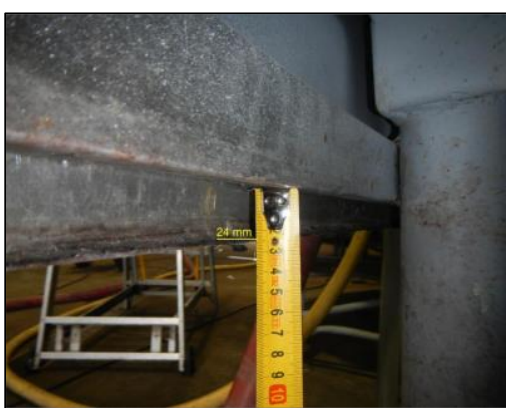

(f) Legged tank settlement: Less than 1\% in 2013

Figure 13 (Continued): Typical damage types for legged tanks with percentage of each damage type. 


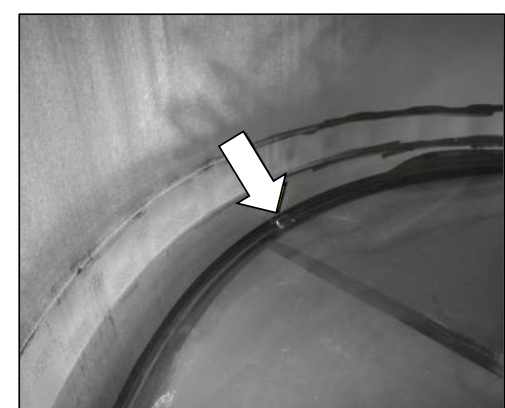

(g) Base punching: $30.3 \%$ in 2013 (16.9\% in 2016)

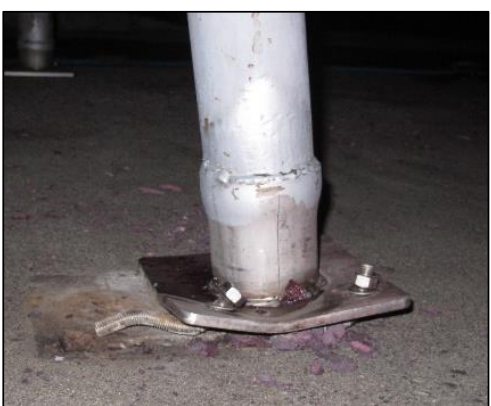

(j) Buckled feet: $4.0 \%$ in 2013

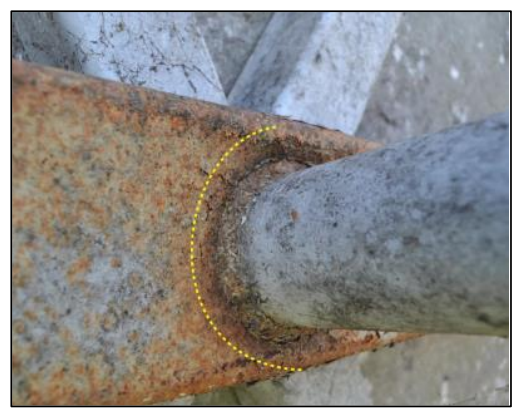

(h) Frame distress: $6.7 \%$ in 2013 (9.3\% in 2016)

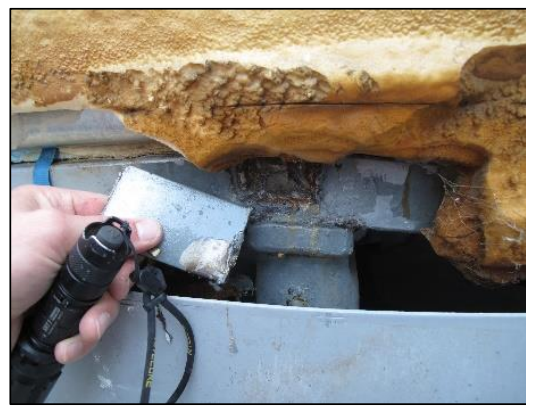

(k) Tab rupturing: $1.6 \%$ in 2013 (9.7\% in 2016)

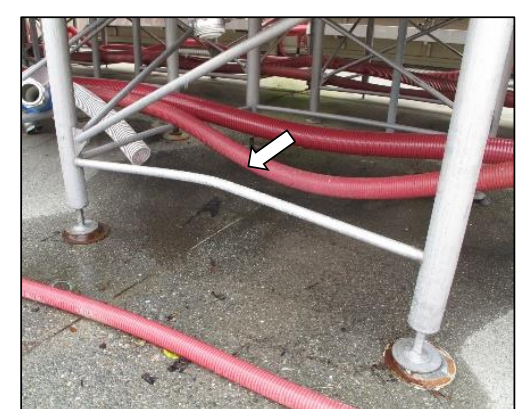

(i) Brace buckling: $<1 \%$ in 2013 (1.7\% in 2016)

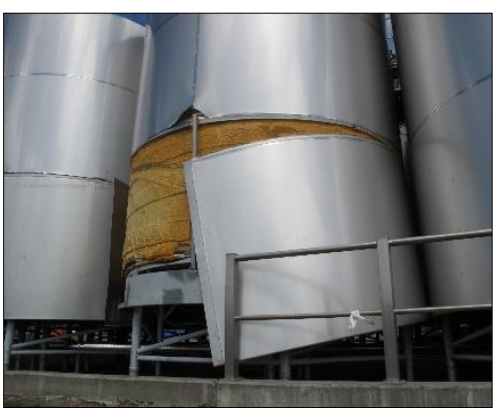

(l) Barrel other:

$0.5 \%$ in 2013 (11.5\% in 2016)

Figure 13: Typical damage types for legged tanks with percentage of each damage type.

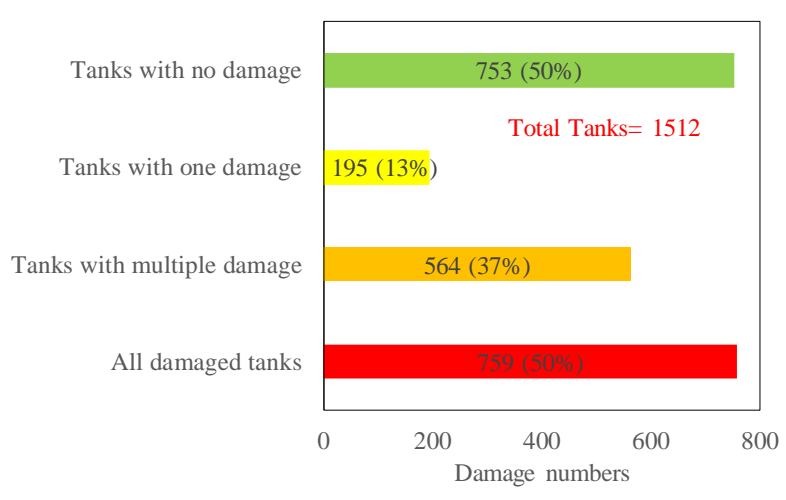

(a) 2013 earthquakes

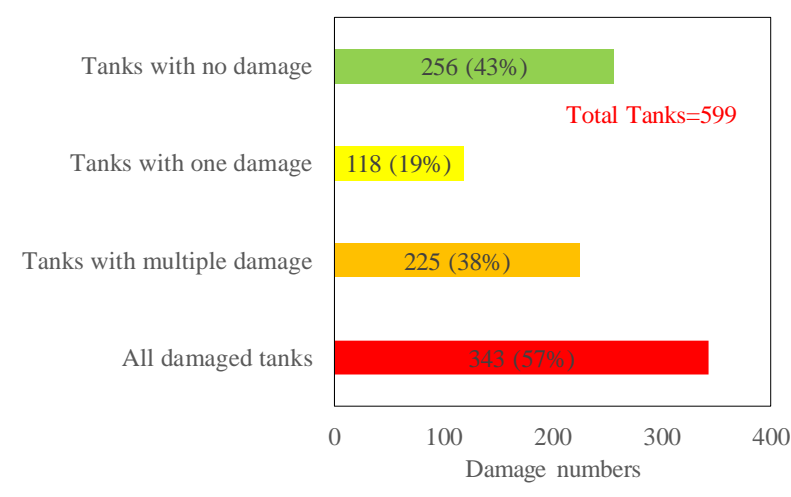

(b) 2016 earthquake

Figure 14: Summary of damage to legged tanks. 


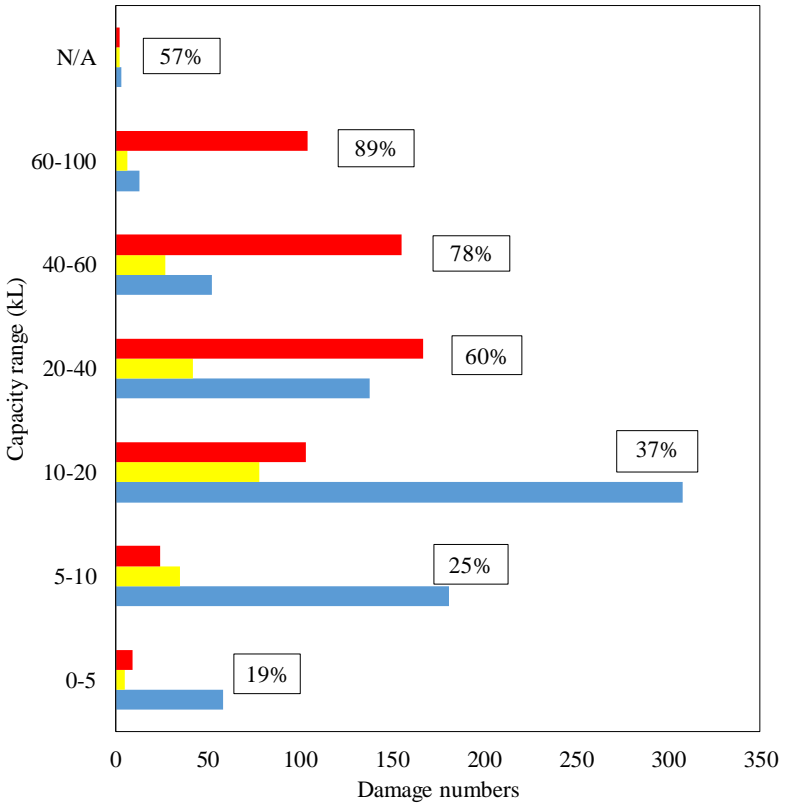

- Tanks with multiple damage $₫$ Tanks with one damage $₫$ Tanks with no damage

(a) 2013 earthquakes

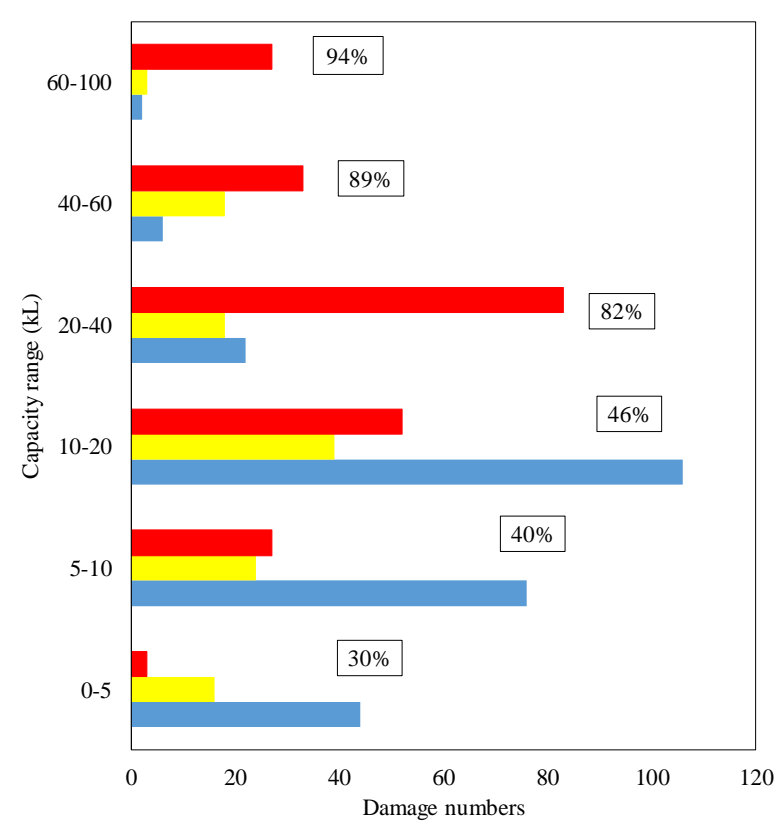

- Tanks with multiple damage $\amalg$ Tanks with one damage $\square$ Tanks with no damage

(b) 2016 earthquake

Figure 15: Damage percentage to legged tanks based on tank capacity range.

(Note: \% in the figures relates to the total percentage of damaged tanks for that capacity range)

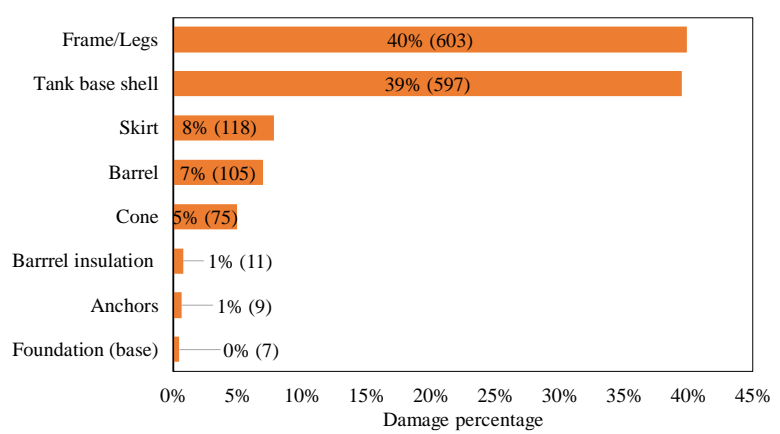

(a) 2013 earthquakes

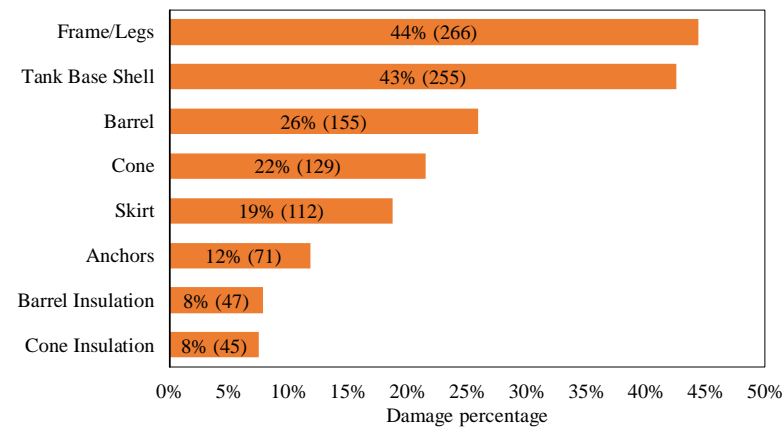

(b) 2016 earthquake

Figure 16: Percentage of damage to different parts of legged tanks.

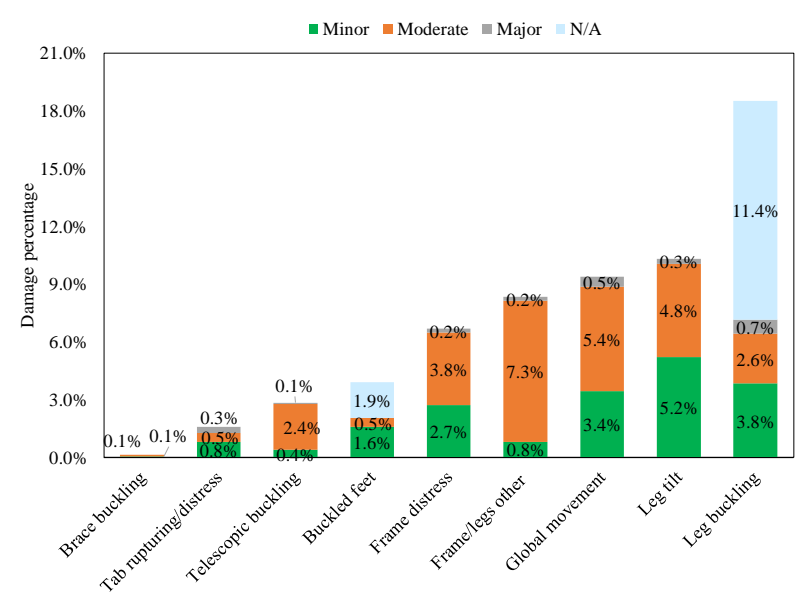

(a) 2013 earthquakes

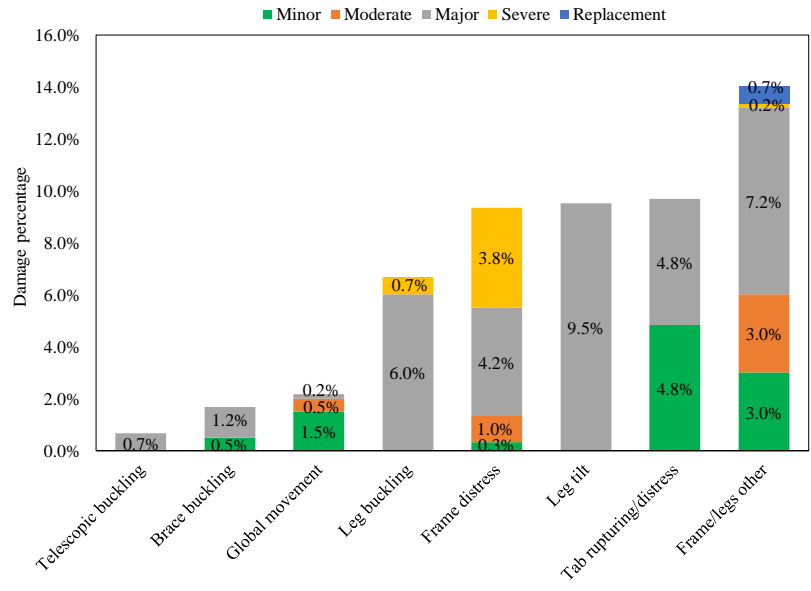

(b) 2016 earthquake

Figure 17: Percentage of different failure modes that caused damage to the frame and legs of legged tanks. 


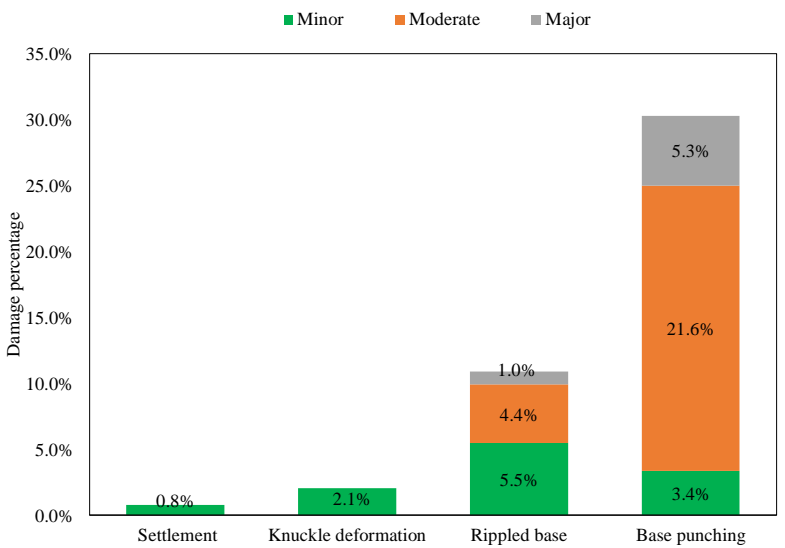

(a) 2013 earthquakes

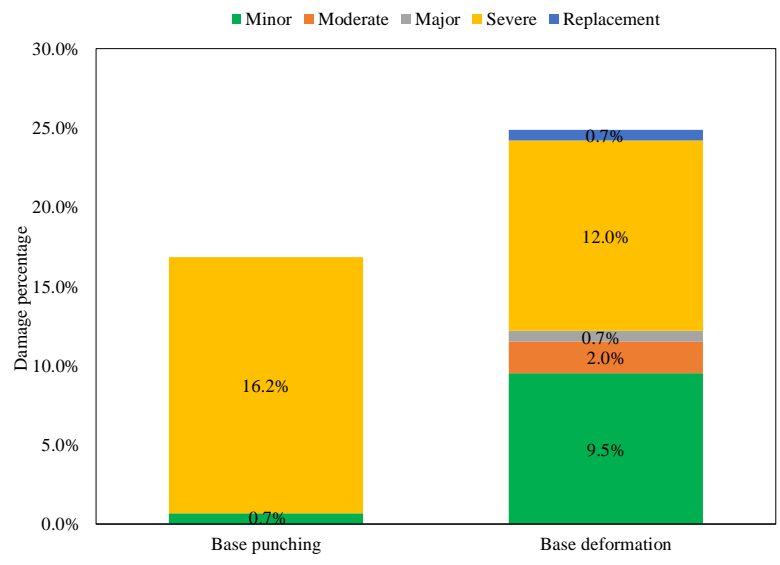

(b) 2016 earthquake

Figure 18: Percentage of different failure modes that caused damage to the tank base shell of legged tanks.

\section{CASE STUDIES OF REPAIRS TO THE ANCHORAGE SYSTEM AND FRAME/LEGS OF TANKS}

Following the 2013 earthquakes the structural engineers who inspected the wineries reported herein were tasked with developing registers of recommended repairs for the purpose of insurance claims. Because winery stakeholders are typically tolerant of minor levels of earthquake damage if the equipment remains adequately operational, it is likely that not all recommended repairs were implemented by winery stakeholders. Details of the recommended repairs for both flatbased and legged wine tanks following the 2013 earthquakes are presented in this section.

\section{Flat-based Tanks}

Detailed reports of the recommended repairs to the anchorage systems of flat-based wine tanks following the 2013 earthquakes were analysed for three of the reported wineries. Because wine tanks are secured with a number of anchors distributed around the tank perimeter, it is common that some anchors will sustain damage whilst other anchors remain undamaged. Based on an analysis of the recommended repairs, all three wineries required the replacement of anchorage systems for some of their wine tank stock (see Table 4), where $74 \%$ (28 out of 38) of flat-based tanks in winery ID 1 required anchor bolt replacement (see Figure 19), on average requiring 12 anchor bolts to be replaced for each tank (see Table 4). In winery ID 3 and ID $446 \%$ (11 out of 24) and 44\% (36 out of 84) of flat-based tanks required anchor bolt replacement, with on average 4 anchors requiring replacement for each tank in winery ID 3 and on average 8 anchors requiring replacement for each tank in winery ID 4 (see Table 4).

Whilst $74 \%$ of the 38 flat-based tanks in winery ID 1 required anchor bolt replacement, only 18\% (7 tanks) required bracket replacement (see Table 4) and in winery ID 3 and ID 4 there were no reported cases of tanks requiring bracket replacement. It is notable that there was a low percentage of bracket replacement for the flat-based tanks (see Figure 12). Postearthquake damage observations showed that brackets were damaged when the skirt part of the tank was also damaged (see Figure 3c).

\section{Legged Tanks}

Detailed reports on repair recommendations for the frame/legs of legged wine tanks in the three wineries (see Table 5) indicated that $68 \%$ of legged tanks in winery ID 1 had damage to their frame/legs, although in this winery only $8 \%$ of all tanks having damage to their legs were recommended to have leg replacement (see Table 5). Winery ID 3 and ID 4 had similar data (see Table 5). The low proportion of recommended leg replacements was due to several factors, such as: (i) damage to the legs of legged wine tanks may not impede the functionality of the tank; (ii) winery stakeholders may adopt temporary remedial options for legged wine tanks which do not require detailed engineering retrofit or conceptual retrofit design. For example, it was frequently observed that winery stakeholders used either wooden blocks (see Figure 20) or welded steel plates (see Figure 21) as temporary remediation solutions.

A large percentage of tanks in all three wineries required frame/legs reinforcement $(14 \%, 17 \%$, and 19\%) when compared with tanks that required leg replacement $(8 \%, 10 \%$, and $3 \%)$. A critique of this data shows that for damaged legged wine tanks the preference of winery stakeholders and/or the recommendation of engineers was to use temporary and lowcost remedial options. Based on in-field observations and investigations, many of the damaged and non-compliant legged wine tanks were replaced or strengthened to flat-based tanks following the 2013 and 2016 earthquakes.

Table 4: Extent of post-earthquake repairs to the anchorage system of flat-based wine tanks following the 2013 earthquakes.

\begin{tabular}{|c|c|c|c|c|c|}
\hline $\begin{array}{c}\text { Winery } \\
\text { ID }\end{array}$ & $\begin{array}{c}\text { Number of flat- } \\
\text { based tanks }\end{array}$ & $\begin{array}{c}\text { Number of tanks with } \\
\text { anchor bolt } \\
\text { replacement }\end{array}$ & $\begin{array}{c}\text { Average number of } \\
\text { replaced anchors } \\
\text { for tanks }\end{array}$ & $\begin{array}{c}\text { Number of tanks with } \\
\text { bracket replacement }\end{array}$ & $\begin{array}{c}\text { Average number of } \\
\text { replaced bracket } \\
\text { for tanks }\end{array}$ \\
\hline$(1)$ & 38 & $28(74 \%)$ & 12 & $7(18 \%)$ & $7(18 \%)$ \\
\hline$(3)$ & 24 & $11(46 \%)$ & 4 & 0 & 0 \\
\hline$(4)$ & 82 & $36(44 \%)$ & 8 & 0 & 0 \\
\hline
\end{tabular}


Table 5: Extent of post-earthquake repairs to frame/legs of legged wine tanks following the 2013 earthquakes.

\begin{tabular}{|c|c|c|c|c|c|c|}
\hline Winery ID & $\begin{array}{c}\text { Number of } \\
\text { legged wine } \\
\text { tanks }\end{array}$ & $\begin{array}{c}\text { Number of } \\
\text { tanks with } \\
\text { frame/legs } \\
\text { damage }\end{array}$ & $\begin{array}{c}\text { Number of tanks } \\
\text { with leg } \\
\text { replacement }\end{array}$ & $\begin{array}{c}\text { Average } \\
\text { number of } \\
\text { replaced legs }\end{array}$ & $\begin{array}{c}\text { Number of tanks } \\
\text { with leg/frame } \\
\text { strengthening }\end{array}$ & $\begin{array}{c}\text { Average number } \\
\text { of leg/frame } \\
\text { strengthening }\end{array}$ \\
\hline$(1)$ & 125 & $85(68 \%)$ & $10(8 \%)$ & $1(1 \%)$ & $17(14 \%)$ & $1(1 \%)$ \\
\hline$(3)$ & 252 & $164(65 \%)$ & $26(10 \%)$ & $2(1 \%)$ & $42(17 \%)$ & $1(0 \%)$ \\
\hline$(4)$ & 147 & $93(63 \%)$ & $4(3 \%)$ & $1(1 \%)$ & $28(19 \%)$ & $1(1 \%)$ \\
\hline
\end{tabular}

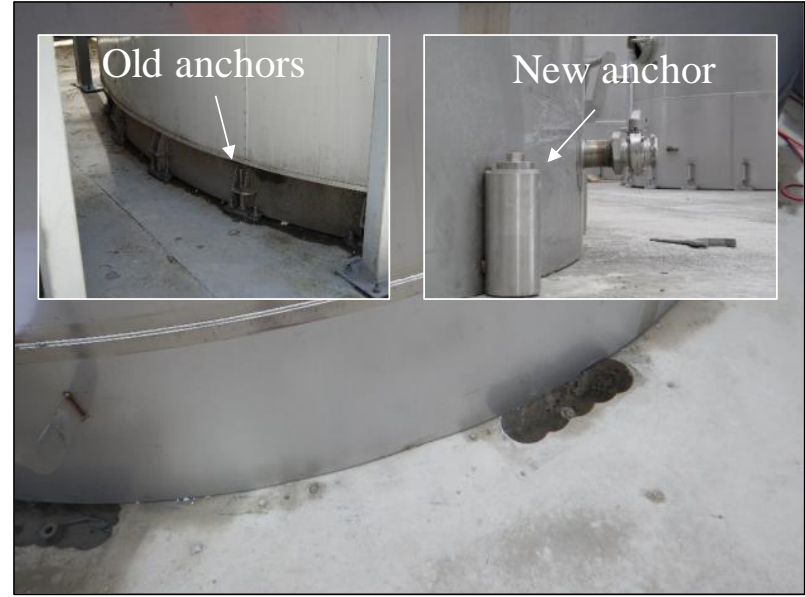

(a) Anchor bolt replacement for tank with $225 \mathrm{~kL}$ capacity

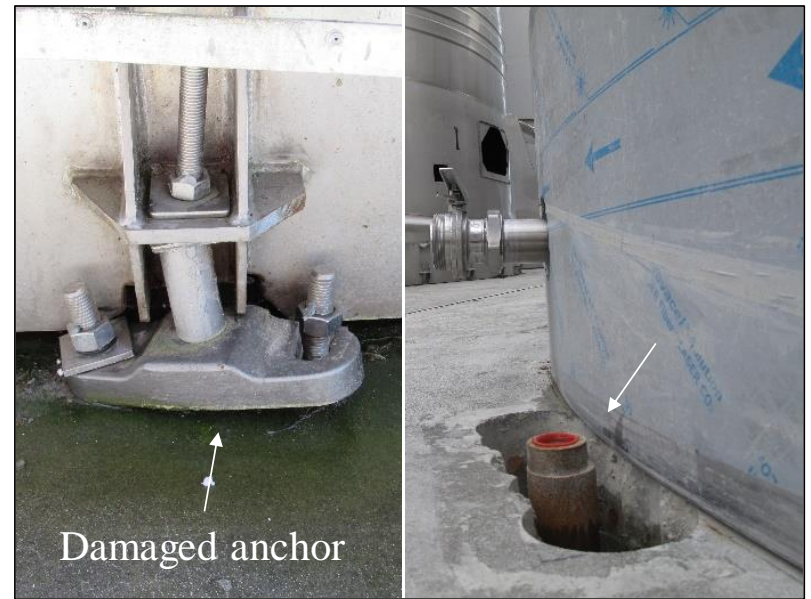

(b) Damaged anchor and preparation of concrete to locate a new anchor

Figure 19: Typical examples of anchor bolt replacement.

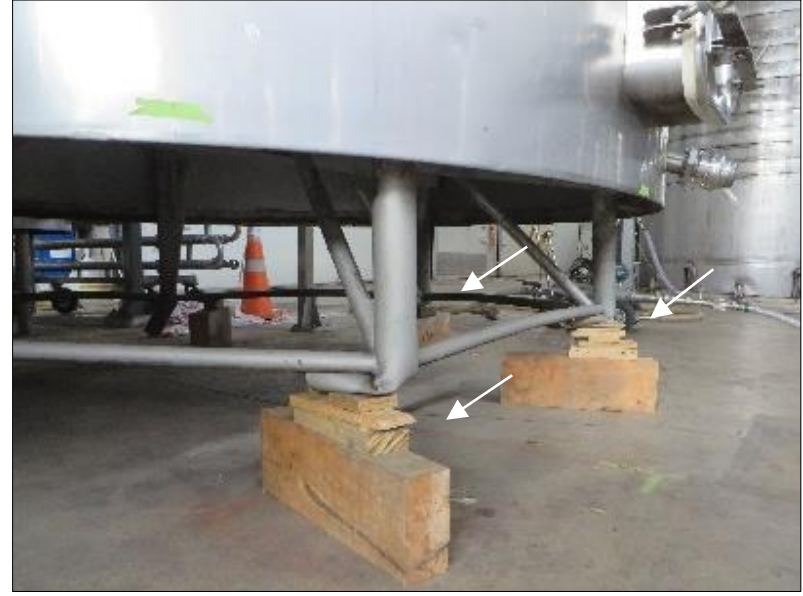

Figure 20: Example of wooden blocks temporarily used to support legged tank.

\section{IMPLICATION OF DAMAGE DATA AND RECOMMENDATION}

The earthquake damage data reported herein has contributed to an increased understanding of the seismic performance of wine storage tanks in the Marlborough region. The NZSEE guideline [43] provides extensive information for calculating seismic design actions in accordance with NZS 1170.5 and covers a wide range of liquid storage tanks. Based on the reported postearthquake winery investigations, it was observed that some of the damaged wine tanks were designed in accordance with the NZSEE guidelines, which suggests that this guideline should be used with caution for the design of stainless steel wine storage tanks. Au et. al [41] reported a number of issues associated with the design of wine storage tanks using the NZSEE guideline,

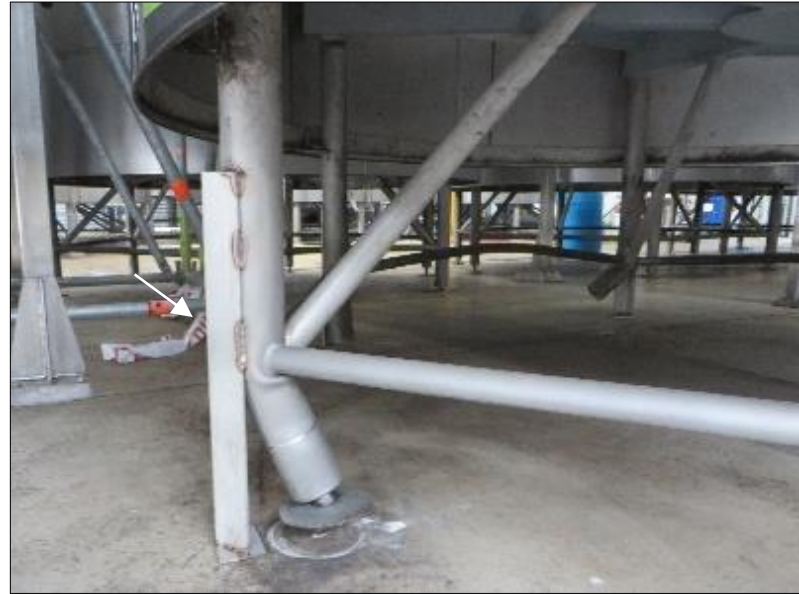

Figure 21: Example of welded steel angle temporarily used to support legged tank.

such as noting that wine tanks are typically sealed so that the liquid convective (sloshing) mode is constrained and the total wine mass acts in the impulsive mode. While the NZSEE guideline does address sealed wine tanks, the document does not clearly explain for designers how treatment of the impulsive mode should be appropriately modified to account for the absence of a convective term. Also, the NZSEE guideline does not provide a methodology for how to assess the strength of the tank cone to resist impact loads due to constrained sloshing, leaving designer to instead use other methods such as computerised finite element modelling [41]. As shown in prior sections, in many cases catwalks are fixed to wine tanks at the top part of the tank barrel which can cause damage to the tank barrel during an earthquake. The current NZSEE guideline does not provide information about catwalks and how the associated 
seismic loads needs to be addressed if a tank has a jointed catwalk [8]. Similarly, the NZSEE guideline does not provide information regarding the design of legged wine tanks, while a large percentage of this type of wine tank sustained damage in the 2013 and 2016 earthquakes.

The current NZSEE guideline [43] has no legal standing and in some cases the guideline is open to alternate interpretations by different designers, such as when selecting Importance Level. The guideline recommends that the default design life for the installation of a new tank should be 50 years but that the selection of Importance Level is the responsibility of the tank designer, with some guidance provided within the document on appropriate selection. Tank designers typically select either Importance Level 1 or Importance Level 2, where Importance level 1 is for structures presenting a low degree of hazard to life and other property while Importance Level 2 is for normal structures and structures not in other importance levels. Within the NZSEE guidelines, Tables 3.4 to 3.7 explain the application of AS/NZS 1170 with respect to the selection of importance levels for storage tanks, stating that the importance level shall be selected according to the most severe consequence of failure. Each of these tables provide information with reference to different risk classifications. For example, Table 3.4 delineates the life safety risk from the tank failure based on the potential number of persons within $50 \mathrm{~m}$ of the tank, while the number of people located in proximity to a tank in a winery can be interpreted differently and is typically dependent on the season and whether the tank is located within the indoor or outdoor part of the winery. In addition, there is no comment within the current guideline on how the importance level should be altered if a tank has a jointed catwalk. Given that $90 \%$ of New Zealand wine resources are located in regions of high seismicity and recognising the ambiguities in the existing NZSEE guideline, it is recommended that a specific tank design standard be developed for stainless-steel storage tanks. Additionally, it is noted that $30 \%$ of dairy resources in New Zealand are also located within regions of high seismicity, and that the geometry and mechanical characteristics of dairy storage tanks are similar to wine storage tanks. Thus, a design standard for stainless-steel storage tanks will be applicable to both the wine and dairy industries. The quantitative and qualitative analysis reported herein related to damaged and undamaged elements of wine tanks can be used to facilitate the development of a new stainless-steel storage tank design standard.

It is important to note however, the potential impact of introducing compulsory tank design standards for New Zealand wineries. Results of ongoing work by social scientists following the 2016 earthquake [47] find such developments would have significant socio-economic implications for winery operations, particularly relating to increased compliance costs associated with replacement or retrofitting existing tanks. While such a development may appear to be a valuable strategy to enhance seismic resilience, the introduction of mandatory standards for tanks may increase risks for some operators. Across New Zealand, wineries range in size from small, boutique producers to corporates that are often owned by overseas investors. Corporate wineries often have considerable financial latitude and greater capability and capacity to respond to changing compliance and production demands. Furthermore, at the other end of the spectrum, small wineries increasingly outsource much of their processing, effectively transferring risks associated with winemaking, bottling and storage to other companies [47]. These larger processing facilities then, bear any compliance costs. Medium-sized wineries, however, lack corporates' resources and economies of scale, and at the same time, may be too big to cost effectively outsource processing, and so maintain control of the entire production process, from growing grapes to making and storing wine. Reliant on limited storage capacity, smaller vintages, and without access to corporate capital, they carry more risk than the boutique wineries, and have fewer options at their disposal for how to respond should new standards be imposed.

These differences in latitude are apparent in the response of winery stakeholders to the 2013 earthquakes [47]. Corporate wineries immediately ordered new tanks, and contracted engineering firms to install new earthquake-resilient tanks or retrofit existing tanks with the newest innovations in seismic anchoring systems. A winery owner in explaining their shift away from legged tanks noted that, "After the Seddon earthquake in 2013 that [legged tank design] sort of became old hat because if you're on legs and you get lifted up the legs then puncture the bottom of the tank" [47]. By contrast after the same event another winery described having to replace damaged legged-tanks with other legged-tanks because of financial constraints, despite recognising other technology was superior. There are concerns now that wineries in this situation may be unable to obtain insurance if tanks do not meet a retroactively imposed standard, and yet may lack financial capital to replace existing tanks.

In order to successfully introduce design standards and building codes for tank design therefore, it may first be necessary to gain additional insight into the potential consequences for wineries, in particular to better understand the needs, values and priorities of medium-sized operators. With continued growth in the wine industry [1], the tank capacity across the country will continue to increase. It will be important to ensure seismic resilience to future events, while not creating additional undue hardship or complications for some operators. Finally, any changes will require open and transparent consultation across the industry to broker innovative and effective, and equitable engineering solutions. As one operator stated, with regard to replacing tanks post-earthquake: "We are working to a standard, but that standard is not required under the Building Code, so I suppose that's something that needs to change, in our opinion". The question is how, and when.

\section{SUMMARY AND CONCLUSIONS}

An overview of the world's largest damage database for flatbased and legged wine storage tanks is presented herein using earthquake damage data collected following the 2013 Seddon earthquake $\left(\mathrm{M}_{\mathrm{w}} 6.5\right)$, the 2013 Lake Grassmere earthquake $\left(M_{w}\right.$ 6.6), and the 2016 Kaikōura earthquake $\left(M_{w}\right.$ 7.8). The reported data included the post-earthquake damage assessment of 2058 wine storage tanks from the 2013 earthquakes (1512 legged and 546 flat-based wine storage tanks) and 1401 wine storage tanks from the 2016 earthquake (599 legged and 802 flat-based wine storage tanks). Based upon high-level discussions and the results reported herein, the following conclusions can be drawn:

- Low aspect ratio flat-based wine tanks with capacities of $400 \mathrm{~kL}$ and $550 \mathrm{~kL}$ performed well, where 13 tanks (59\%) sustained mostly minor damage of the tank base shell or tank barrel.

- In the 2013 earthquakes the tank base shell (39\%) and anchor (47\%) parts of flat-based wine tanks were the most damaged elements, while in the 2016 earthquake the barrel (54\%) and cone (43\%) parts of flat-based tanks sustained the largest percentage of damage.

- A critique of damage data revealed that $10.0 \%$ and $24.4 \%$ of flat-based tanks sustained damage to their barrels due to indenting of catwalk in 2013 and 2016 earthquakes, respectively. It should be noted that in the 2016 earthquake, only $58 \%$ of the tanks in the inventory had tank-supported catwalks.

- In both the 2013 and 2016 earthquakes the increased level of earthquake-related damage due to increasing tank storage capacity had a more pronounced trend for legged wine tanks when compared with flat-based wine tanks. 
- Based on the damage data and in-field observations, winery stakeholders did more retrofit on flat-based wine tanks compared with the legged wine tanks. It has been also noted that many of the damaged and non-compliant legged wine tanks were replaced or strengthened to flat-based tanks following the 2013 and 2016 earthquakes.

It is recommended that a design code be specifically developed for stainless-steel storage tanks that includes both flat-based and legged wine tanks. The results presented herein will assist the identification of issues that need to be addressed in such a design code to ensure that the most vulnerable elements of wine tanks will remain undamaged in future large earthquakes. It is also recommended that a guideline for the seismic assessment of existing stainless-steel storage tanks be developed, so that engineers can assess existing wine storage tanks and identify tanks that are potentially earthquake prone.

\section{ACKNOWLEDGMENT}

This is an updated and extended version of a paper presented at the Eleventh Pacific Conference on Earthquake Engineering (PCEE) at Auckland in April 2019. The authors express their appreciation to the Ministry for Primary Industries (NZ) for the financial support (Project 5000132) provided to the authors to conduct this research project, and to the Thornton Tomasetti Company (Wellington, NZ office) for providing the majority of the information reported in this research. The authors also express their appreciation to Structex for their technical advice and Vinod Sadashiva from GNS Science who helped the authors establish the appropriate PGA values for the 2013 earthquakes.

\section{REFERENCES}

1 NZ Wine (2018). New Zealand Winegrowers Annual Report.

https://www.nzwine.com/en/media/statistics/annualreport. (Accessed: 17 July 2019).

2 Karl A (2018). "Attitudes toward Sustainable New Zealand Wine held by Millennials in the United States". Masters Thesis, University of Canterbury, Christchurch, New Zealand.

3 Standards New Zealand (2004). "NZS1170.5: Structural Design Actions. Part 5: Earthquake Actions-New Zealand". Standards New Zealand, Wellington, $76 \mathrm{pp}$.

4 Dizhur D, Simkin G, Giaretton M, Loporcaro G, Palermo A and Ingham J (2017). "Performance of winery facilities during the 14 November 2016 Kaikōura earthquake". Bulletin of the New Zealand Society for Earthquake Engineering, 50(2): 206-224.

5 Yazdanian M, Ingham JM, Dizhur D and Kahanek C (2019). "A conspectus of wine storage tank damage data following the 2013 and 2016 New Zealand earthquakes". 2019 Pacific Conference on Earthquake Engineering, Auckland, New Zealand.

6 Morris GJ, Bradley BA, Walker A and Matuschka T (2013). "Ground motions and damage observations in the Marlborough region from the 2013 Lake Grassmere earthquake". Bulletin of the New Zealand Society for Earthquake Engineering, 46(4): 169-186.

7 Rosewitz J and Kahanek C (2014). "Performance of wine storage tanks: Lessons from the earthquakes near Marlborough". Australasian Structural Engineering Conference (ASEC), Auckland, New Zealand, 9-11 July.

8 Yazdanian $\mathrm{M}$, Ingham JM, Kahanek $\mathrm{C}$ and Dizhur D (2020). "Damage to flat-based wine storage tanks in the 2013 and 2016 New Zealand earthquakes". Journal of Constructional Steel Research, 168: 105983.

9 Amiri M and Sabbagh-Yazdi SR (2011). "Ambient vibration test and finite element modeling of tall liquid storage tanks". Thin-walled Structures, 49(8): 974-983.
10 Molin B and Remy F (2013). "Experimental and numerical study of the sloshing motion in a rectangular tank with a perforated screen". Journal of Fluids and Structures, 43: 463-480.

11 Virella JC, Prato CA and Godoy LA (2008). "Linear and nonlinear 2D finite element analysis of sloshing modes and pressures in rectangular tanks subject to horizontal harmonic motions". Journal of Sound and Vibration, 312(3): 442-460.

12 Yazdanian M and Ghasemi S (2017). "Study on fundamental frequencies of cylindrical storage tanks obtained from codes and finite element method". Civil Engineering Infrastructures Journal, 50(1): 135-149.

13 Benasciutti D, Moro L and Cimenti N (2014). "Seismic analysis of a liquid storage tank used in wine industry: a FEM-based approach". International CAE Conference, Italy, 27-28 October.

14 Hosseinzadeh N, Kazem H, Ghahremannejad M, Ahmadi E and Kazem N (2013). "Comparison of API650-2008 provisions with FEM analyses for seismic assessment of existing steel oil storage tanks". Journal of Loss Prevention in the Process Industries, 26(4): 666-675.

15 Moslemi M and Kianoush MR (2012). "Parametric study on dynamic behavior of cylindrical ground-supported tanks". Engineering Structures, 42: 214-230.

16 Spritzer JM and Guzey S (2017). "Nonlinear numerical evaluation of large open-top aboveground steel welded liquid storage tanks excited by seismic loads". Thin-Walled Structures, 119: 662-676.

17 Yazdanian M, Razavi V and Mashal M (2016). "Study on the dynamic behavior of cylindrical steel liquid storage tanks using finite element method". Journal of Theoretical and Applied Vibration and Acoustics, 2(2): 145-166.

18 Ozdemir Z, Souli M and Yasin MF (2012). "Numerical evaluation of nonlinear response of broad cylindrical steel tanks under multidimensional earthquake motion". Earthquake Spectra, 28(1): 217-238.

19 Spritzer JM and Guzey S (2017). "Review of API 650 Annex E: Design of large steel welded aboveground storage tanks excited by seismic loads". Thin-Walled Structures, 112: 41-65.

20 Eshghi S and Razzaghi MS (2007). "Performance of cylindrical liquid storage tanks in Silakhor, Iran earthquake of March 31, 2006". Bulletin of the New Zealand Society for Earthquake Engineering, 40(4): 173-182.

21 Moeini M and Goudarzi MA (2018). "Seismic damage criteria for a steel liquid storage tank shell and its interaction with demanded construction material". Bulletin of the New Zealand Society for Earthquake Engineering, 51(2): 70-84.

22 Ruiz RO, Lopez-Garcia D and Taflanidis AA (2015). "An efficient computational procedure for the dynamic analysis of liquid storage tanks". Engineering Structures, 85: 206218.

23 Malhotra PK, Wenk T and Wieland M (2000). "Simple procedure for seismic analysis of liquid-storage tanks". Structural Engineering International, 10(3): 197-201.

24 Cortes G and Prinz GS (2017). "Seismic fragility analysis of large unanchored steel tanks considering local instability and fatigue damage". Bulletin of Earthquake Engineering, 15(3): 1279-1295.

25 Hosseinzadeh N, Sangsari MK and Ferdosiyeh HT (2014). "Shake table study of annular baffles in steel storage tanks as sloshing dependent variable dampers". Journal of Loss Prevention in the Process Industries, 32: 299-310.

26 Cooper TW and Wachholz TP (1999). "Performance of petroleum storage tanks during earthquakes 1933-1995". Optimizing Post-Earthquake Lifeline System Reliability (pp. 878-886), ASCE.

27 American Lifeline Alliance (ALA) (2001). "Seismic fragility formulation for water system: Part 1-Guideline". 
ASCE.

28 American Lifeline Alliance (ALA) (2001). "Seismic fragility formulation for water system: Part 2- Guideline". ASCE.

29 Manos GC (1991). "Evaluation of the earthquake performance of anchored wine tanks during the San Juan, Argentina, 1977 earthquakexs". Earthquake Engineering and Structural Dynamics, 20(12): 1099-1114.

30 Fischer EC, Liu J and Varma AH (2016). "Investigation of cylindrical steel tank damage at wineries during earthquakes: Lessons learned and mitigation opportunities". Practice Periodical on Structural Design and Construction, 21(3): 04016004.

31 Fischer E (2014). "Learning from Earthquakes: 2014 Napa Valley Earthquake Reconnaissance Report". West Lafayette, Indiana, USA.

32 Earthquake Engineering Research Institute (1990). "Loma Prieta Earthquake Reconnaissance Report: Supplement C'. 6: 25-80.

33 González E, Almazán J, Beltrán J, Herrera R and Sandoval V (2013). "Performance of stainless steel winery tanks during the 02/27/2010 Maule Earthquake". Engineering Structures, 56: 1402-1418.

34 Galloway B and Ingham J (2015). "The 2014 South Napa earthquake and its relevance for New Zealand". SESOC Journal, 28(1): 69.

35 Yazdanian M, Ingham JM, Lomax W, Wood R and Dizhur D (2020). "Damage observations and remedial options for approximately 1500 legged and flat-based liquid storage tanks following the 2016 Kaikōura earthquake". Structures, 24: 357-376.

36 Moehle JUB, Riddell RUC and Boroschek RUC (2010). "8.8 Chile Earthquake of February 27, 2010". EERI Special Earthquake Report, 10: 1-20.

37 GeoNet (2016). New Zealand Earthquake Report: Magnitude 7.8, Mon, Nov 14, 2016, 12:02:56 am (NZDT).

38 Bradley BA, Razafindrakoto HN and Nazer M (2017). "Strong ground motion observations of engineering interest from the 14 November $2016 \mathrm{M}_{\mathrm{w}}$ 7. 8 Kaikōura, New
Zealand earthquake". Bulletin of the New Zealand Society for Earthquake Engineering, 50(2): 85-93.

39 Bruneau M, Chang SE, Eguchi RT, Lee GC, O'Rourke TD, Reinhorn AM, ... and Von Winterfeldt D (2003). “A framework to quantitatively assess and enhance the seismic resilience of communities". Earthquake Spectra, 19(4): 733-752.

40 Crowley K and Elliott JR (2012). "Earthquake disasters and resilience in the global North: lessons from New Zealand and Japan". The Geographical Journal, 178(3): 208-215.

41 Au EV, Walker AF and Lomax WJ (2015). "Wine industry implementation of the NZSEE guidance on the seismic design of liquid storage tanks". NZSEE Annual Conference, Rotorua, New Zealand, 10-12 April.

42 Priestley MJN (1986). "Seismic Design of Storage Tanks: Recommendations of a Study Group of the New Zealand National Society for Earthquake Engineering". New Zealand National Society for Earthquake Engineering, Wellington, New Zealand.

43 NZSEE (2009). "Seismic Design of Storage Tanks: Recommendations of a NZSEE Study Group on Seismic Design of Storage Tanks". New Zealand National Society for Earthquake Engineering, Wellington, New Zealand.

44 Wald DJ, Worden BC, Quitoriano V and Pankow KL (2006). "ShakeMap®manual". Technival Manual, Users Guide, Software Guide Version.

45 Savarimuthu $\mathrm{S}$ et al. (2017). "SeisFinder: A web application for extraction of data from computationally intensive earthquake resilience calculations".

46 Sobhan MS, Rofooei FR and Attari NK (2017). "Buckling behavior of the anchored steel tanks under horizontal and vertical ground motions using static pushover and incremental dynamic analyses". Thin-Walled Structures, 112: $173-183$.

47 Cradock-Henry NA and Fountain J (2019). "Characterising resilience in the wine industry: insights and evidence from Marlborough, New Zealand”. Environmental Science and Policy, 94: 182-190. 